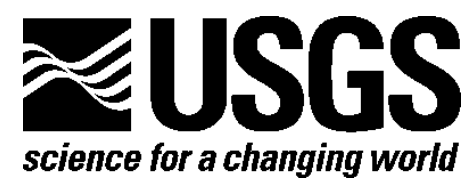

First Steps of Integrated Spatial Modeling of Titanium, Zirconium, and Rare Earth Element Resources within the Coastal Plain Sediments of the Southeastern United States

By Karl J. Ellefsen, Bradley S. Van Gosen, David L. Fey, James R. Budahn, Steven M. Smith, and Anjana K. Shah

Open-File Report 2015-1111

U.S. Department of the Interior

U.S. Geological Survey 


\section{U.S. Department of the Interior \\ SALLY JEWELL, Secretary}

\section{U.S. Geological Survey \\ Suzette M. Kimball, Acting Director}

U.S. Geological Survey, Reston, Virginia: 2015

For more information on the USGS-the Federal source for science about the Earth,

its natural and living resources, natural hazards, and the environment-visit

http://www.usgs.gov or call 1-888-ASK-USGS

For an overview of USGS information products, including maps, imagery, and publications, visit http://www.usgs.gov/pubprod

To order this and other USGS information products, visit http://store.usgs.gov

Suggested citation:

Ellefsen, K.J., Van Gosen, B.S., Fey, D.L., Budahn, J.R., Smith, S.M., and Shah, A.K., 2015, First steps of integrated spatial modeling of titanium, zirconium, and rare earth element resources within the Coastal Plain sediments of the southeastern United States: U.S. Geological Survey Open-File Report 2015-1111, 40 p., http://dx.doi.org/10.3133/ofr20151111.

ISSN 2331-1258 (online)

Any use of trade, firm, or product names is for descriptive purposes only and does not imply endorsement by the U.S. Government.

Although this information product, for the most part, is in the public domain, it also may contain copyrighted materials as noted in the text. Permission to reproduce copyrighted items must be secured from the copyright owner. 


\section{Contents}

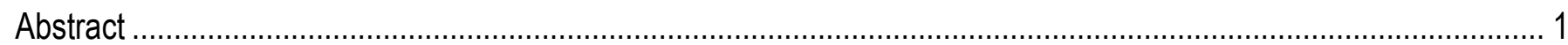

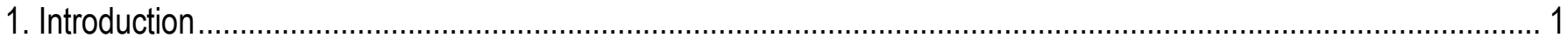

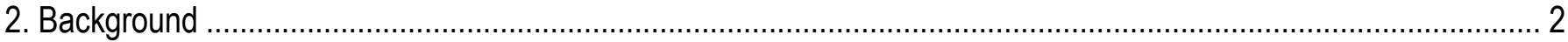

2.1 Minerals Containing Titanium, Zirconium, and the Rare Earth Elements ..................................................... 2

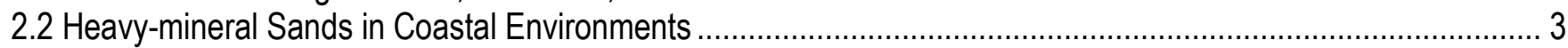

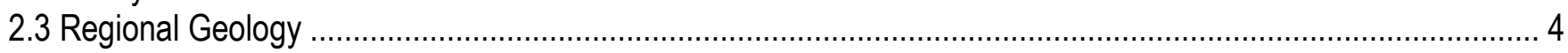

2.4 Study Area

2.5 Compositional Data

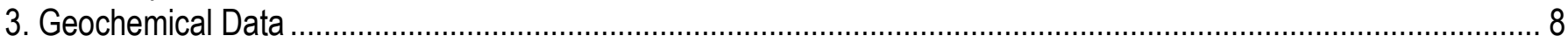

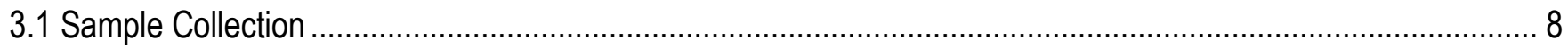

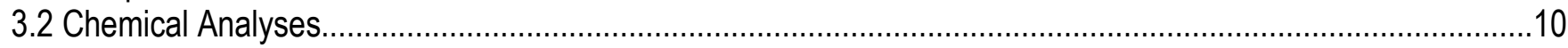

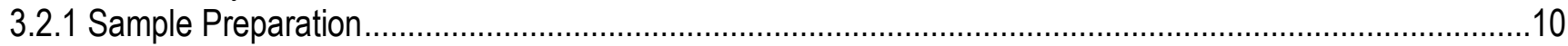

3.2.2 Inductively Coupled Plasma-Atomic Emission Spectrometry ..............................................................10

3.2 .3 Instrumental Neutron Activation Analysis ......................................................................................11

3.2.4 Discussion of Chemical Analyses...................................................................................................

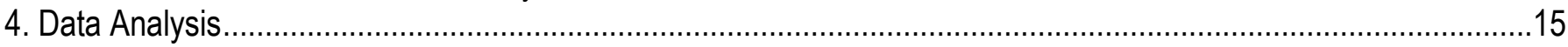

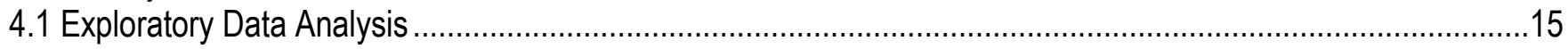

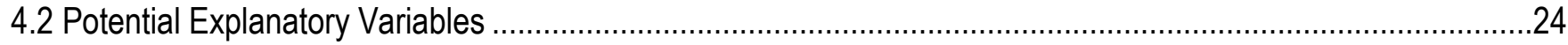

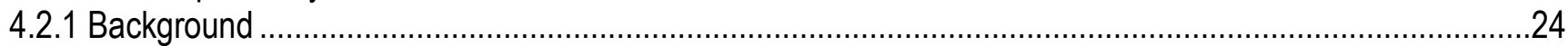

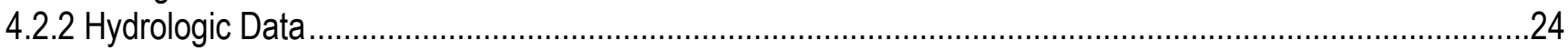

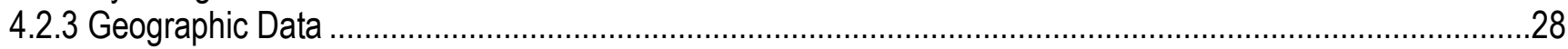

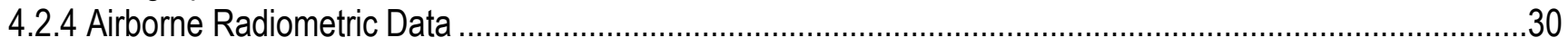

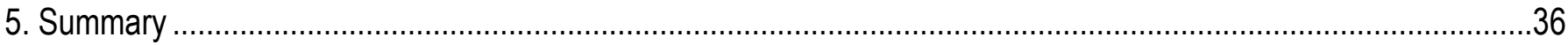

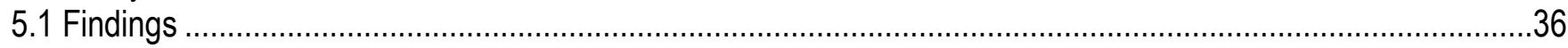

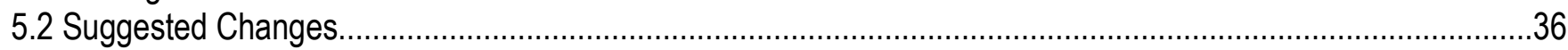

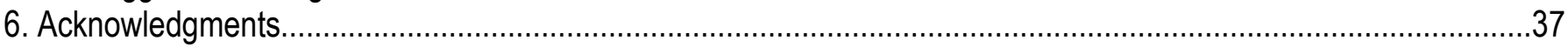

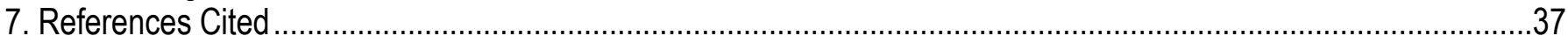

\section{Figures}

1. Cross section showing features commonly used to describe shoreline (strandline) depositional environments associated with deposits of heavy-mineral sands.

2. Generalized geologic map of the Atlantic Coastal Plain of the southeastern United States, showing features

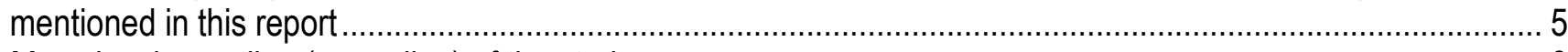

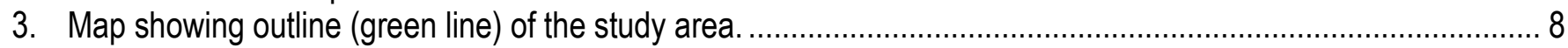

4. Maps showing locations of samples that were chemically analyzed by $A$, ICP-AES and $B$, INAA ....................... 10

5. Scatterplots of samples measured with both ICP-AES and INAA for elements $A$, La; $B$, Ce; and C, Nd ........... 12

6. Graphs showing associations among the element concentrations for monazite within the study area................. 16

7. Graphs showing associations among the element concentrations for xenotime within the study area................. 17

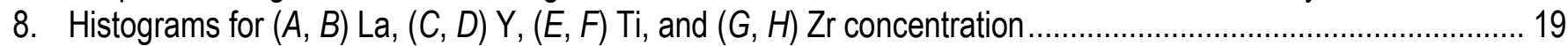

9. Graph showing empirical cumulative distribution functions for $(A, B) \mathrm{La},(C, D) \mathrm{Y},(E, F) \mathrm{Ti}$, and $(G, H) \mathrm{Zr}$

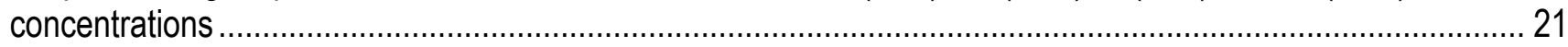

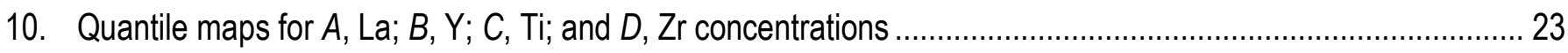

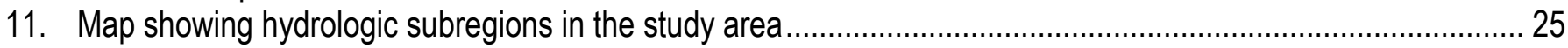

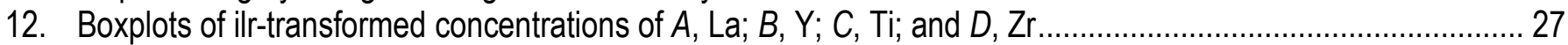


13. Scatterplots showing that the ilr-transformed concentration depends on distance from the Fall Line for $A$, La; $B, Y ; C, T i$ and $D, Z r$

14. Map showing survey and tie lines of the airborne radiometric survey that are within the study area 31

15. Histograms of the eTi concentrations from the airborne radiometric survey

16. Graph showing equivalent thorium (eTh) concentrations along a survey line near the coast of North Carolina.. 32

17. Quantile map of equivalent thorium (eTh) concentrations. 33

18. Graph showing normal score transformation for the equivalent thorium (eTh) concentrations............................ 34

19. Scatterplots showing the relations between the normal score (from the equivalent thorium [eTh] concentration) and the ilr-transform of $A, \mathrm{La} ; B, Y ; C, \mathrm{Ti}$; and $D, \mathrm{Zr}$ concentrations

\section{Tables}

1. Elements, the common minerals containing those elements, and mineral properties ......................................... 2

2. Summary statistics for the geochemical data 


\section{Selected Element Abbreviations}

$\begin{array}{ll}\mathrm{Ce} & \text { cerium } \\ \mathrm{Dy} & \text { dysprosium } \\ \mathrm{Eu} & \text { europium } \\ \mathrm{Er} & \text { erbium } \\ \mathrm{Fe} & \text { iron } \\ \mathrm{Gd} & \text { gadolinium } \\ \mathrm{Hf} & \text { hafnium } \\ \mathrm{Ho} & \text { holmium } \\ \mathrm{La} & \text { lanthanum } \\ \mathrm{Lu} & \text { lutetium } \\ \mathrm{Nd} & \text { neodymium } \\ \mathrm{O} & \text { oxygen } \\ \mathrm{P} & \text { phosphorus } \\ \mathrm{Pr} & \text { praseodymium } \\ \mathrm{Si} & \text { silicon } \\ \mathrm{Sm} & \text { samarium } \\ \mathrm{Tb} & \text { terbium } \\ \mathrm{Th} & \text { thorium } \\ \mathrm{Ti} & \text { titanium } \\ \mathrm{Tm} & \text { thulium } \\ \mathrm{U} & \text { uranium } \\ \mathrm{Y} & \text { yttrium } \\ \mathrm{Yb} & \text { ytterbium } \\ \mathrm{Zr} & \text { zirconium } \\ & \end{array}$




\section{Conversion Factors}

Inch/Pound to SI

\begin{tabular}{lcl}
\hline & \multicolumn{1}{c}{ Multiply } & \multicolumn{1}{c}{ To obtain } \\
\hline & Length & \\
\hline inch (in.) & 2.54 & centimeter (cm) \\
inch (in.) & 25.4 & millimeter (mm) \\
foot (ft) & 0.3048 & meter (m) \\
mile (mi) & 1.609 & kilometer (km) \\
yard (yd) & 0.9144 & meter (m) \\
\hline & Mass & \\
\hline ounce, avoirdupois (oz) & 28.35 & gram (g) \\
pound, avoirdupois (lb) & 0.4536 & kilogram (kg)
\end{tabular}

SI to Inch/Pound

\begin{tabular}{lll}
\hline \multicolumn{1}{c}{ Multiply } & By & \multicolumn{1}{c}{ To obtain } \\
\hline centimeter $(\mathrm{cm})$ & Length & \\
millimeter $(\mathrm{mm})$ & 0.3937 & inch (in.) \\
meter $(\mathrm{m})$ & 0.03937 & inch (in.) \\
kilometer $(\mathrm{km})$ & 3.281 & foot (ft) \\
meter $(\mathrm{m})$ & 0.6214 & mile (mi) \\
\hline & 1.094 & yard (yd) \\
\hline gram $(\mathrm{g})$ & Mass & \\
kilogram $(\mathrm{kg})$ & 0.03527 & ounce, avoirdupois $(\mathrm{oz})$ \\
& 2.205 & pound avoirdupois $(\mathrm{lb})$ \\
\hline
\end{tabular}




\title{
First Steps of Integrated Spatial Modeling of Titanium, Zirconium, and Rare Earth Element Resources within the Coastal Plain Sediments of the Southeastern United States
}

By Karl J. Ellefsen, Bradley S. Van Gosen, David L. Fey, James R. Budahn, Steven M. Smith, and Anjana K. Shah

\begin{abstract}
The Coastal Plain of the southeastern United States has extensive, unconsolidated sedimentary deposits that are enriched in heavy minerals containing titanium, zirconium, and rare earth element resources. Areas favorable for exploration and development of these resources are being identified by geochemical data, which are supplemented with geological, geophysical, hydrological, and geographical data. The first steps of this analysis have been completed. The concentrations of lanthanum, yttrium, and titanium tend to decrease as distance from the Piedmont (which is the likely source of these resources) increases and are moderately correlated with airborne measurements of equivalent thorium concentration. The concentrations of lanthanum, yttrium, and titanium are relatively high in those watersheds that adjoin the Piedmont, south of the Cape Fear Arch. Although this relation suggests that the concentrations are related to the watersheds, it may be simply an independent regional trend. The concentration of zirconium is unrelated to the distance from the Piedmont, the equivalent thorium concentration, and the watershed. These findings establish a foundation for more sophisticated analyses using integrated spatial modeling.
\end{abstract}

\section{Introduction}

The Coastal Plain of the southeastern United States contains extensive, unconsolidated sedimentary deposits that are enriched in titanium, zirconium, and rare earth element resources. These resources, especially the rare earth elements, are economically important (Goonan, 2011). Because the deposits are unconsolidated, it is relatively easy and inexpensive to mine them. Indeed, these sedimentary deposits have been mined since 1887 (Overstreet, 1967, p. 106-273; Mertie, 1975, p. 1) and are currently being mined (Van Gosen and others, 2014, p. 18-23).

Because of the economic importance of these resources, U.S. Geological Survey (USGS) personnel began a regional investigation to identify favorable areas for future exploration and development. The investigation is comprehensive and includes pertinent earth-science data, such as geochemical, geological, geophysical, hydrological, and geographical data. These different types of data should be interpreted in an integrated, quantitative manner. This interpretation should be performed using integrated spatial modeling that is a type of Bayesian hierarchical modeling. Such modeling has several advantages: (1) the model assumptions are explicitly specified, (2) the model accounts for the geologic processes that concentrated the resources, and (3) the model can be improved iteratively. The final result of the modeling will be maps showing the probabilities for the resource concentrations; areas 
with high probabilities for high concentrations will be favorable for future exploration and development. To the best of our knowledge, this type of integrated spatial modeling has not been used previously for regional resource investigations. The first steps of such modeling include assembling the pertinent data, determining its limitations, analyzing its properties, and analyzing the relations among the different data types. This report summarizes these first steps.

\section{Background}

\subsection{Minerals Containing Titanium, Zirconium, and the Rare Earth Elements}

In the Coastal Plain sediments of the southeastern United States, titanium, zirconium, and the rare earth element resources elements occur in the minerals that are listed in table 1 . Before the regional geology is discussed (section 2.3), it is helpful to understand the properties of these minerals, because these properties strongly affect the spatial distribution of the minerals and, hence, the resources. The mineralogical information in this section was compiled from Gaines and others (1997), Hurlbut and Klein (1977), Mills and others (2009), Ni and others (1995), and Rapp and Watson (1986).

Titanium commonly occurs within the minerals rutile and ilmenite in the Coastal Plain sediments (table 1). These two minerals belong to the mineral class of oxides, in which various metals are chemically combined with oxygen. Oxide minerals, including rutile and ilmenite, are commonly hard, dense, and refractory (which means that they are resistant to chemical weathering). They are common accessory minerals in igneous rocks and high-grade metamorphic rocks, and they commonly occur as detrital grains in sediments. Leucoxene is an alteration product of several different titanium minerals including ilmenite.

Zirconium commonly occurs within the mineral zircon in the Coastal Plain sediments (table 1). Zircon belongs to the nesosilicate mineral subclass; the atomic structure of this subclass is based on silicon tetrahedra $\left(\mathrm{SiO}_{4}\right)$ that are bound together by cations such as $\mathrm{Zr}$. The tetrahedra are densely packed together, causing the minerals to be both hard and dense. Zircon is refractory, but its crystalline structure is commonly disrupted because of radiation from $\mathrm{U}$. Like rutile and ilmenite, zircon is a common accessory mineral in igneous and metamorphic rocks, and zircon commonly occurs as detrital grains in sediments.

Table 1. Elements, the common minerals containing those elements, and mineral properties. The listed association between elements and minerals pertains to the Coastal Plain sediments in the southeastern United States.

\begin{tabular}{|c|c|c|c|}
\hline Element & Mineral & Mineral composition & Mineral specific gravity \\
\hline \multirow{3}{*}{ Titanium } & Rutile & $\mathrm{TiO}_{2}$ & $4.2-4.3$ \\
\hline & Ilmenite & $\mathrm{FeTiO}_{3}$ & 4.7 \\
\hline & Leucoxene & $\mathrm{FeTiO}_{3}$ to mostly $\mathrm{TiO}_{2}$ & $3.8-4.2$ \\
\hline Zirconium & Zircon & $(\mathrm{Zr}, \mathrm{Hf}, \mathrm{U}) \mathrm{SiO}_{4}$ & 4.7 \\
\hline Light rare-earth elements & Monazite & ( $\mathrm{La}, \mathrm{Ce}, \mathrm{Pr}, \mathrm{Nd}, \mathrm{Sm}, \mathrm{Eu}, \mathrm{Gd}) \mathrm{PO}_{4}$ & $4.6-5.4$ \\
\hline Heavy rare-earth elements & Xenotime & (Tb, Dy, Ho, Er, Tm, Yb, Lu, Y) $\mathrm{PO}_{4}$ & $4.4-5.1$ \\
\hline
\end{tabular}

The light rare earth elements (namely, La, Ce, Pr, Nd, Sm, Eu, and Gd) occur within the mineral monazite in the Coastal Plain sediments (table 1). Monazite belongs to the phosphate mineral class; the atomic structure of this class is based on phosphorus tetrahedra $\left(\mathrm{PO}_{4}\right)$. All mineral phases have identical stoichiometry but different crystalline structure depending on the ionic radius of the rare earth element. Cerium constitutes approximately 45 weight percent of the light rare elements in monazite, La approximately 24 weight percent, $\mathrm{Nd}$ approximately 17 weight percent, and the other rare earth 
elements even smaller percentages. Monazite commonly includes Th and U, making it radioactive. Monazite is both dense and refractory. Monazite occurs as an accessory mineral in granites, gneisses, aplites, and pegmatites, and in sands derived from those rocks.

The heavy rare earth elements (namely, Tb, Dy, Ho, Er, Tm, Yb, Lu, Y) occur within the mineral xenotime in the Coastal Plain sediments (table 1). Xenotime also belongs to the phosphate mineral class. Like monazite, all mineral phases have identical stoichiometry but different crystalline structure depending on the ionic radius of the rare earth element. Yttrium constitutes roughly 67 weight percent of the heavy rare elements in xenotime. Each of the even-number lanthanides (namely, Dy, Er, and $\mathrm{Yb}$ ) constitutes approximately 5 weight percent, and each of the odd-number lanthanides (namely, $\mathrm{Tb}, \mathrm{Ho}, \mathrm{Tm}$, and $\mathrm{Lu}$ ) constitutes approximately 1 weight percent. Like monazite, xenotime commonly includes Th and $U$, making it radioactive. Xenotime occurs as a minor accessory mineral in igneous rocks, gneisses, and pegmatites.

Distinguishing features of the minerals listed in table 1 are their specific gravities - the minerals are dense compared to many common minerals. For example, the specific gravity for quartz, which is the dominant mineral in the Atlantic Coastal Plain (Smith and others, 2014) is 2.65. The minerals listed in table 1 are categorized as "heavy minerals," which are defined as minerals having specific gravities greater than 2.85 (Luepke, 1984). Specific gravity, as well as particle shape, significantly affects particle settling in both air and water (Friedman and Sanders, 1978, p. 37), so heavy minerals in sedimentary environments tend to be concentrated as placers (Garnett and Bassett, 2005).

Another distinguishing feature of the minerals listed in table 1 is that they are refractory; some have persisted since at least the Cretaceous period. Their refractory nature also affects chemical dissolution and, hence, their chemical analyses (section 3.2.2).

\subsection{Heavy-mineral Sands in Coastal Environments}

Heavy-mineral sands are sedimentary deposits of dense minerals that accumulate with sand, silt, and clay in coastal environments, locally forming economic concentrations of the heavy minerals (Force, 1991; Hou and others, 2011; Van Gosen and others, 2014). This deposit type is the main source of titanium feedstock for the titanium dioxide $\left(\mathrm{TiO}_{2}\right)$ pigments industry, through recovery of the titanium minerals ilmenite, rutile, and leucoxene (an alteration product of ilmenite) (table 1). This deposit type is also the principal source of zircon and its zirconium oxide. Other heavy minerals produced as coproducts from some coastal deposits are sillimanite, kyanite, staurolite, monazite, garnet, and xenotime. Monazite is a source of rare earth elements as well as thorium. Heavy-mineral sands deposits are relatively easy to mine because they are weakly to poorly consolidated, and they are relatively easy to process by employing gravity, magnetic, and electrostatic separation techniques (Young and Luttrell, 2012).

Heavy-mineral sands are formed by the physical-mechanical concentration of bedrock minerals freed by weathering. The process begins inland of the coast where igneous, metamorphic, and sedimentary rocks erode and contribute detritus of sand, silt, clay, and heavy minerals to stream drainages. Streams and rivers carry the sediments to a coastal area, where they are deposited and redistributed in a variety of environments (Force, 1991; Van Gosen and others, 2014), such as deltas (Frihy, 1994), the beach face (foreshore), the shoreface, barrier islands, dunes, and tidal lagoons, as well as the channels and floodplains of streams and rivers in the coastal plain. Along the coast, the actions of waves, tides, and wind mechanically sort the mineral grains and naturally segregate heavy, high-density minerals from lower-density minerals. The finest-grained, most dense heavy minerals are the most sorted. These sorting processes can deposit discrete thin layers and composite intervals in the sediments composed of dominantly heavy minerals. The resulting strata are laminated or lens-shaped, heavy- 
mineral-rich sedimentary packages that can be as much as tens of meters thick. Studies indicate that the most significant sites of heavy-mineral accumulation are where the sediments are deposited in aeolian sand dunes, and the foreshore, shoreface, and lagoonal (backshore) environments (fig. 1) (Force, 1991).

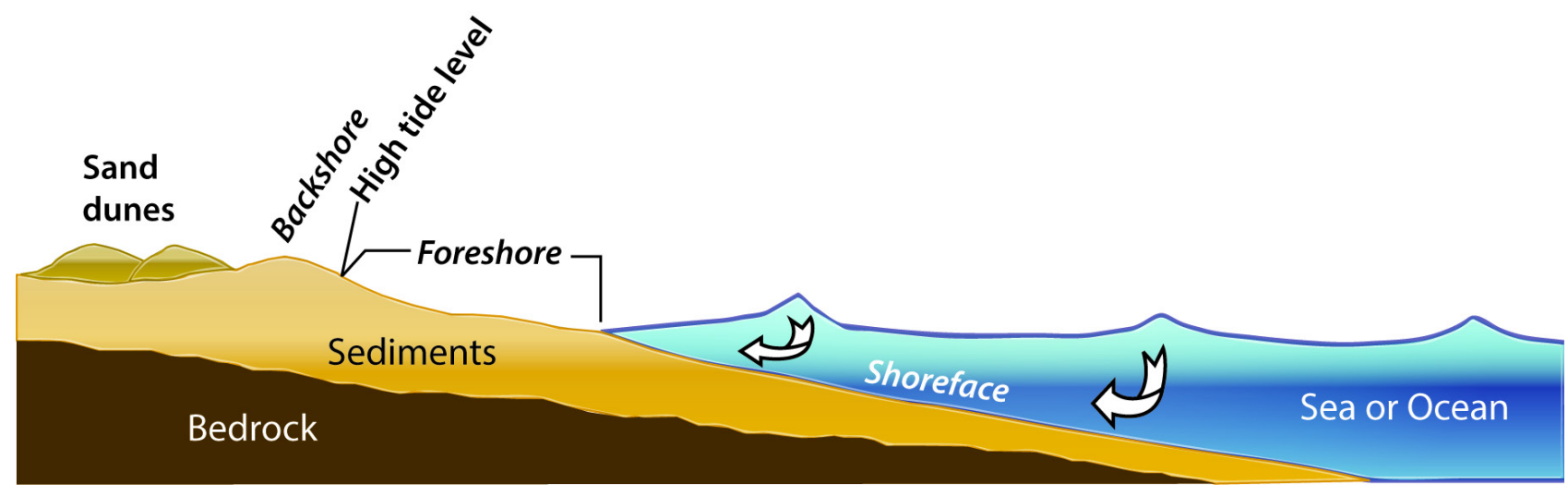

Figure 1. Features commonly used to describe shoreline (strandline) depositional environments associated with deposits of heavy-mineral sands. Not to scale.

Economic deposits of heavy-mineral sands encompass modern and ancient examples. Globally, heavy-mineral sands operations have exploited deposits that range in age from Cretaceous to Recent coastal deposits. Most of the recently mined heavy-mineral sands are Paleogene, Neogene, and Quaternary (including modern sediments) in age. These heavy-mineral sands formed during alternating transgressions and regressions of the seas and were subsequently modified by many factors (Van Gosen and others, 2014). Through an understanding of modern sedimentary systems, we are able to readily interpret and understand the geology and morphology of ancient coastal deposits (McKellar, 1975; Force, 1991; Roy, 1999; Hou and others, 2006, 2008, 2011; Van Gosen and others, 2014).

The resulting deposits of heavy-mineral sands can be voluminous; examples of economic deposits are described in Van Gosen and others (2014). Many heavy-mineral sands districts extend for more than 10 kilometers $(\mathrm{km})$ and contain several individual deposits that are spread along an ancient or modern strandline. Reported thicknesses of economic deposits range from 3 to 45 meters (m). Individual ore deposits typically contain at least 10 million metric tonnes of ore (the total size of the individual heavy-mineral sands body), where the overall heavy-mineral content ranges from 2 percent to greater than 10 percent.

\subsection{Regional Geology}

Because of the common, regional, downstream association of heavy-mineral sands with highgrade metamorphic rocks and the strong relation between metamorphic grade and titanium mineralogy, rocks of sillimanite and higher metamorphic grade are considered the principal source of ilmenite and rutile in coastal sands (Force, 1976; Van Gosen and others, 2014). In the southeastern United States (fig. 2), from Virginia to Florida, ilmenite is ubiquitous in heavy-mineral sands of the Atlantic Coastal Plain. The source of this ilmenite and of the associated heavy minerals has been attributed to an extensive area of sillimanite-grade metamorphism within the Blue Ridge and Piedmont regions that lie west of the Coastal Plain (Mertie, 1953; Force, 1976). 


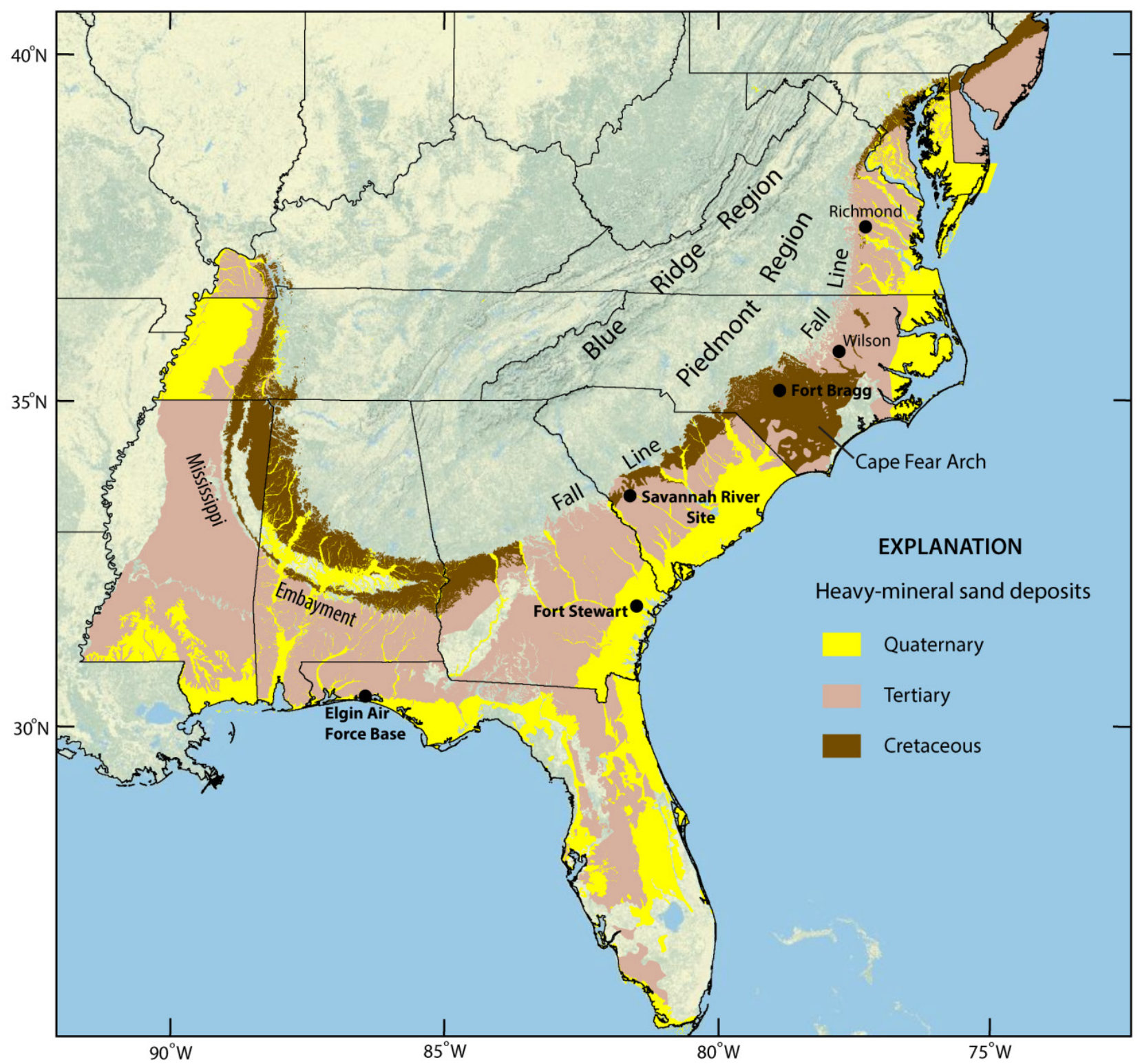

Figure 2. Generalized geologic map of the Atlantic Coastal Plain of the southeastern United States, showing features mentioned in this report. Mismatches in the geologic units across some of the State boundaries are due to differences in mapped units within the individual State geologic maps, which were used to compile the geology in this figure.

In addition to the titanium oxide minerals, most of the other heavy minerals in the Atlantic Coastal Plain heavy mineral suite are those typical of intermediate- to high-grade metamorphic rocks. For example, in addition to ilmenite and rutile, common heavy minerals in coastal sands are garnets, staurolite, monazite, xenotime, and kyanite or sillimanite. Similarly, monazite in the ancient, as well as modern, coastal heavy-mineral sands of the Coastal Plain was presumably transported by fluvial systems originating in high-grade metamorphic rocks of the Piedmont (Overstreet, 1967; Overstreet and others, 1968). 
Igneous rocks also can be significant sources of the heavy minerals that are ultimately deposited in coastal environments. Proposed igneous sources of the heavy minerals must account for ilmenite and rutile, the most abundant of the economic heavy minerals in heavy-mineral sands. Force (1991) provides a detailed discussion of the igneous rocks that are most enriched in $\mathrm{TiO}_{2}$ and contain an abundance of $\mathrm{Ti}$ oxide minerals. The author describes several magmatic rock associations as potential sources of ilmenite or rutile, such as anorthosite-ferrodiorite massifs and associated contact-metasomatic rutile deposits; alkaline igneous complexes, particularly pyroxenite units in these complexes; some granitoid rocks; some basaltic rocks; layered mafic intrusions; and kimberlites.

Sedimentary rocks can be intermediate hosts of the heavy minerals that later become heavymineral sand deposits. Sedimentary rocks in coastal regions can contain enrichments in heavy minerals derived from erosion of older igneous and metamorphic rocks. Erosion of the sedimentary rocks ("intermediate host rocks") by fluvial processes, storms, waves, and currents along the coast can liberate the detrital heavy minerals from the consolidated sedimentary rocks; in this way the heavy minerals are remobilized and re-deposited, this time in coastal sands (Van Gosen and others, 2014).

The Coastal Plain region of the southeastern United States is the physiographic province that lies east of the "Fall Line." This is a regional term that refers to the contact zone between the basement rocks of the Piedmont region on the west and much younger sediments of the Coastal Plain on the east (also sometimes referred to as the "Fall Zone"). The Coastal Plain extends from the Fall Line to the modern shore (fig. 2). The Coastal Plain is composed mainly of sedimentary strata (mostly poorly consolidated) that was deposited and reworked by a variety of coastal processes. The deposition and morphology of the coastal strata were controlled by alternating periods of strandline transgressions and regressions along the eastern coast of the United States during the Cretaceous, Tertiary, and Quaternary (MacNeil, 1950; Carpenter and Carpenter, 1991; Force, 1991).

Coastal Plain strata were deposited during the Late Cretaceous and have been identified and mapped in southeastern North Carolina. These strata are related to a structural highland in the Coastal Plain referred to as the Cape Fear Arch (Soller, 1988; Grosz and others, 1992) (fig. 2). Additionally, widespread, thick layers of heavy-mineral sands were deposited during Late Cretaceous transgressiveregressive sequences within the Mississippi embayment from Georgia to southern Illinois (Force, 1991) (fig. 2).

In eastern Virginia and North Carolina, abutting the Fall Line (fig. 2), heavy-mineral sand deposits of the upper (western) parts of the Coastal Plain are interpreted to be Pliocene (and possibly late Miocene) deposits that formed during worldwide transgression-regression events between 3.5 and 3.0 million years ago (Ma) (generalized under Tertiary on fig. 2) (Carpenter and Carpenter, 1991; Pirkle and others, 2007). Examples of these strata are exposed along and east of the Fall Line in Sussex County, Virginia (Va.), south of Richmond at the northernmost extent of the Coastal Plain that was analyzed in this study. This weakly consolidated material is composed of heavy-minerals sands that were deposited during the Pliocene (Berquist, 1987). Sand-silt deposits of this type form the heavymineral orebody of the Concord mine operated by Iluka Resources (Iluka Resources, 2014; Van Gosen and others, 2014), located about $75 \mathrm{~km}$ south of Richmond, Va.; their mine and separation plants produce ilmenite, rutile, and zircon. Similar Pliocene coastal strata form a northeast-trending zone of heavy-mineral sand deposits that abut the Fall Line for about $160 \mathrm{~km}$ in length, from Sussex County, Va., southward to east-central North Carolina. The northern end of this belt (zone) includes the Concord deposit and the belt's southern end includes deposits located west of Wilson, North Carolina (Carpenter and Carpenter, 1991, fig. 1). This zone was described by Carpenter and Carpenter (1991) as the "North Carolina-Virginia heavy mineral belt." 
Quaternary strata and unconsolidated sediments containing heavy-mineral accumulations form significant portions of the Coastal Plain of the southeastern United States (for example, MacNeil, 1950; Neiheisel, 1962; Staatz and others, 1980). These heavy-mineral sands deposits range in age from Pleistocene to Holocene. Overstreet (1967) and Staatz and others (1980) describe historic heavy-mineral sands operations in Florida that excavated and processed Quaternary coastal deposits to extract ilmenite, rutile, zircon, and a few other industrial heavy minerals. Many of these operations also recovered and stockpiled monazite as a coproduct (Staatz and others, 1980).

A paleo-reconstruction study of sediment supply to the Gulf of Mexico basin, modeled by Galloway and others (2011), calculated that significant fluvial sediment input occurred into the Mississippian Embayment region (fig. 2) during the Paleocene, Oligocene, Miocene, Pliocene, and Pleistocene. The authors determined that the Paleocene and Pleistocene were periods of especially large sediment supply to the northern coastal region of the Gulf of Mexico (including the Mississippian Embayment). In contrast, the Eocene was a period of relatively minor fluvial input to this region, according to the research of Galloway and others (2011). Their modeling suggests that erosion of the Appalachian Mountains was the principal supply of sediments to the coastal plain of the Mississippian Embayment region.

\subsection{Study Area}

The study area was chosen based on three criteria. First, the study area had to include sedimentary formations with high concentrations of the heavy minerals that originated in the Piedmont. These sedimentary formations are in the Atlantic Coastal Plain and the portion of the Mississippi Embayment that is east of the current Mississippi River (fig. 2). Second, the study area must exclude the flood plains of the Mississippi and Ohio Rivers because they comprise a mixture of fluvial deposits, which would significantly complicate spatial modeling. Third, the study area should encompass complete watersheds because streams and rivers transport the heavy minerals, changing their spatial distribution. Watersheds are defined by the U.S. Geological Survey

(http://water.usgs.gov/GIS/huc.html).

Based on these three criteria, the study area was delimited and is shown in figure 3 . The boundaries of the watersheds commonly differ slightly from the Fall Line; in such cases, the study area was extended into the Piedmont so that watersheds would not be split. All extensions are small (that is, less than $10 \mathrm{~km}$ ), so this portion of the boundary is still called the "Fall Line." 


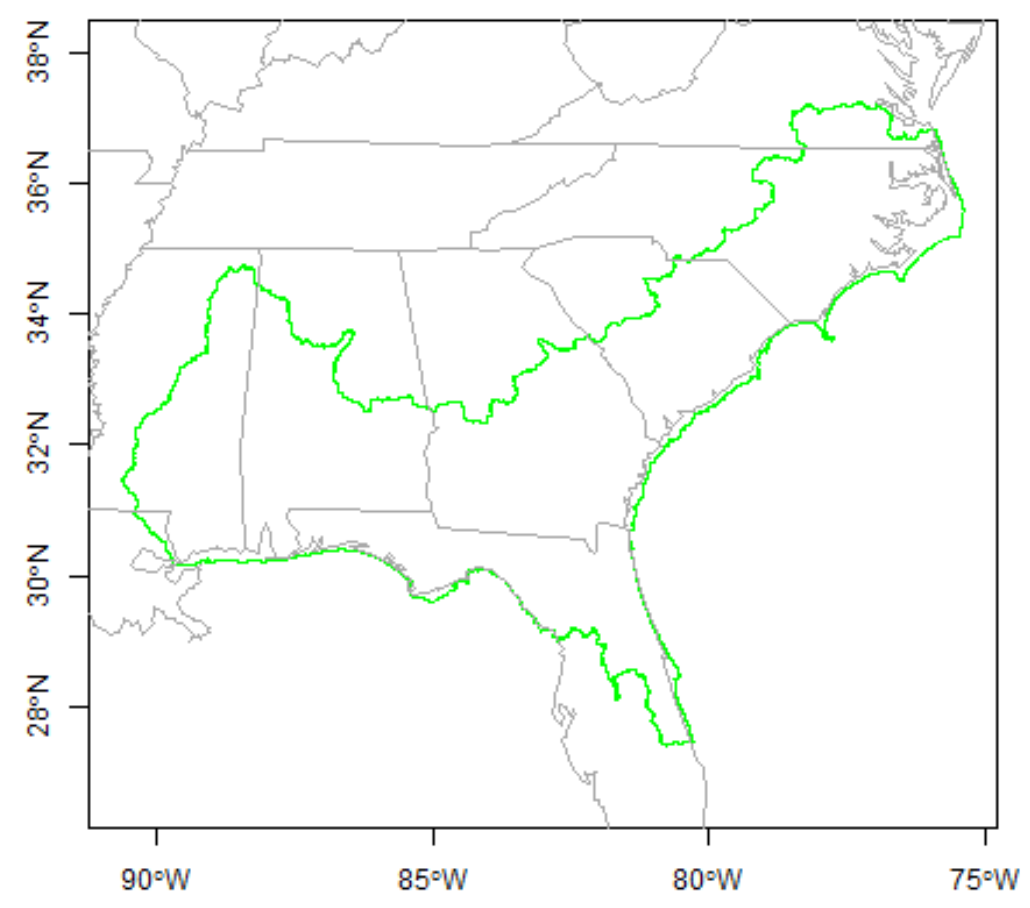

Figure 3. Outline (green line) of the study area.

\subsection{Compositional Data}

The concentrations of titanium, zirconium, and the rare earth elements are geochemical data. Geochemical data have two special properties: The element concentrations are positive, and the sum of all element concentrations is a constant (for example, 100 percent). These two properties define compositional data (Aitchison, 1986, p. 25-28), although now there is a more general, more abstract definition of compositional data (Buccianti and Pawlowsky-Glahn, 2005). If such data are analyzed with standard statistical methods, the inferences may be incorrect (Chayes, 1960; Aitchison, 1986, p. 48-61). Instead, compositional data should be analyzed with special methods (van den Boogaart and TolosanaDelgado, 2013). Readers who are unfamiliar with these methods might consult Aitchison (1986) and Pawlowsky-Glahn and Buccianti (2011).

\section{Geochemical Data}

\subsection{Sample Collection}

There are six national-scale (or almost national-scale) geochemical data sets pertaining to the conterminous United States (Smith and others, 2013), and the data set that is called the "National Geochemical Survey" is used in this investigation. (That is, this investigation uses existing chemical analyses of previously collected samples. These publicly available data can be obtained at U.S. Geological Survey [2004].) For this data set, the sampling density is high, so the spatial modeling will have high spatial resolution. Although the data set includes samples from different geologic media, only those samples from stream sediments are used here. An advantage of stream sediments is that they are a composite of all sediment sources within their watershed. Thus, the stream sediments are more likely to indicate anomalies than soil samples which are localized measurements. Hence, the data from the National Geochemical Survey are well suited for this investigation. 
The National Geochemical Survey data set comprises many different data subsets (U.S. Geological Survey, 2004). It is helpful to consider the data in this report as derived from three groups, based on the sampling protocol. The first group comprises eight data subsets: "NURE Alabama-I," "NURE Alabama-II," "NURE Coastal 98," "NURE Coastal 99," "NURE South Carolina," "NURE 2000," "NURE 2002," and "NURE 800." The samples for these eight data subsets were collected between 1975 and 1980 as part of the National Uranium Resource Evaluation (NURE) program (Smith, 1997). The sampling protocol (Ferguson and others, 1976) specified that a sample be obtained from the largest stream within each small watershed; "small" means a watershed for which the area ranges approximately from 8 to 26 square kilometers. Sampling sites were selected to avoid contamination associated with urban and suburban areas. Each site sample was a composite of five or more subsamples that were collected along $30-150 \mathrm{~m}$ of the stream bottom.

The second group within the National Geochemical Survey data set comprises seven data subsets: "Alabama," "Florida-I," 'Florida-II," "Georgia," "Mississippi-I," "Mississippi-II," and "State stragglers" (U.S. Geological Survey, 2004). These seven data subsets were collected between 1997 and 1999 as part of a collaborative program between the U.S. Geological Survey and the respective State governments. Although various geologic media were chosen for sampling, this report uses only those samples from stream sediments. The sampling protocol specified that approximately one sample be collected from a small stream within a $10-\mathrm{km} \times 10-\mathrm{km}$ square area. Sample locations were chosen to be away from obvious sources of contamination, including roads. Each sample was a composite of 6 to 10 subsamples obtained from different depositional zones within the stream.

The third group within the National Geochemical Survey data set comprises just one data subset: "Louisiana." The sampling protocol and chemical analyses were identical, with one exception, to those for the second group: The exception is the sampling density, which was one sample per $17-\mathrm{km} \times 17-\mathrm{km}$ square area.

For the remainder of this report, the samples are not distinguished by the three different sampling protocols. Instead, the samples are distinguished by the methods used for chemical analyses because the methods significantly affect the reported measurements (section 4). Although several different methods were used for chemical analyses, this report uses data from only two methods: inductively coupled plasma-atomic emission spectrometry (ICP-AES) and instrumental neutron activation analysis (INAA).

There are a total of 4,648 samples within the study area (fig. 4). Of these, 4,645 samples were measured by ICP-AES; 3,180 samples by INAA; and 3,177 samples by both. The sample coverage is approximately uniform, with two notable exceptions: The coverage for ICP-AES samples is very dense in Alabama near the Fall Line, and the coverage for both ICP-AES and INAA samples is sparse in north-central Florida. 

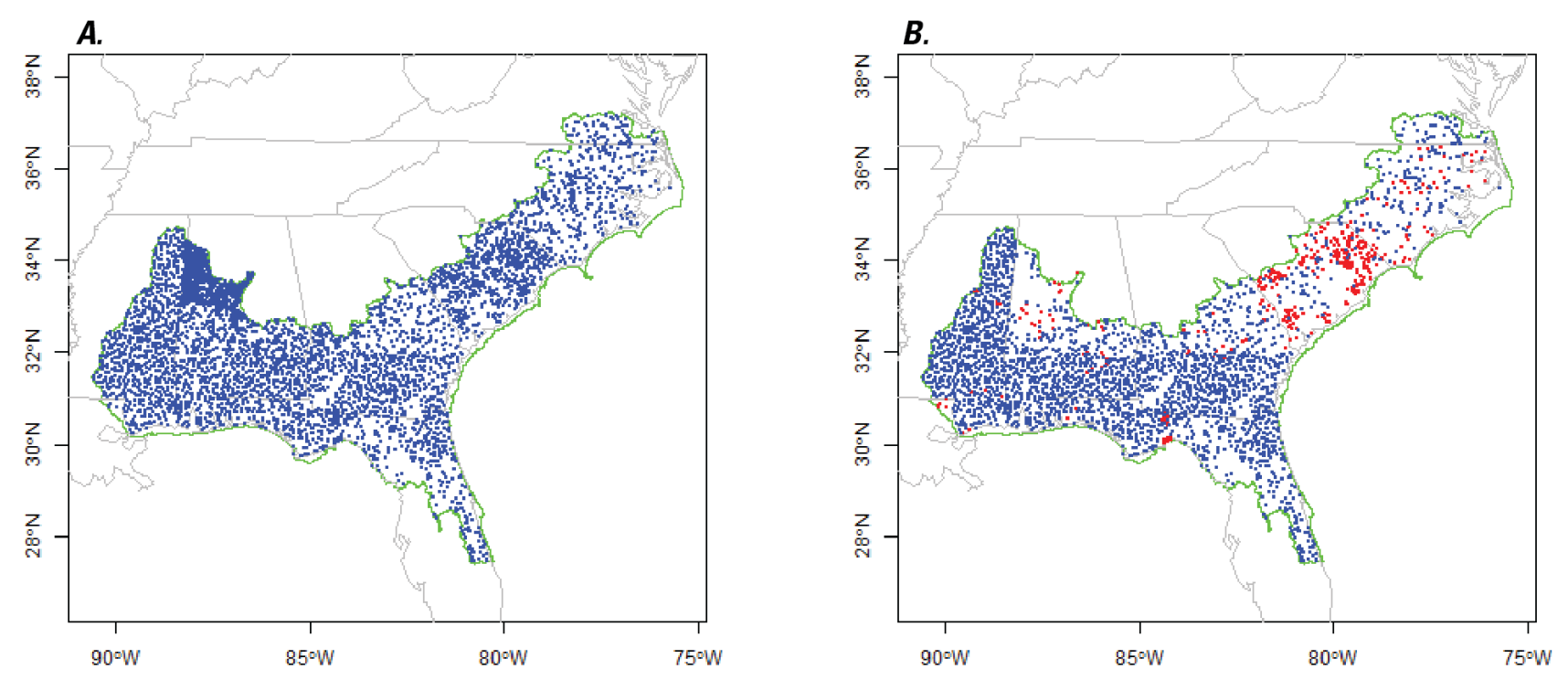

\section{EXPLANATION}

- Samples measured by U.S. Geological Survey

- Samples measured by Becquerel Laboratories

- Border of study area

Figure 4. Locations of samples that were chemically analyzed by $A$, ICP-AES and $B$, INAA. The blue dots indicate samples measured by the U.S. Geological Survey, and the red dots by Becquerel Laboratories. The green polygon represents the border of the study area.

\subsection{Chemical Analyses}

\subsubsection{Sample Preparation}

To prepare the field samples for chemical analysis, they were dried at ambient temperature, disaggregated, and sieved. The grain size after sieving was less than 150 micrometers $(\mu \mathrm{m})$. These preparatory procedures were used for all samples and for both analytical methods.

\subsubsection{Inductively Coupled Plasma-Atomic Emission Spectrometry}

Inductively coupled plasma-atomic emission spectrometry (ICP-AES) was used to measure concentrations for 40 different elements. Each sample was dissolved in a mixture of hydrochloric, nitric, perchloric, and hydrofluoric acids. Additional information about the method is found in Briggs (2002) and U.S. Geological Survey (2004). Of the 40 measured elements, 5 are pertinent to this study: Ce, La, $\mathrm{Nd}, \mathrm{Ti}$, and $\mathrm{Y}$. These five elements are listed in table 2, along with a quantity called the "lower reporting limit," which is a threshold below which measured concentrations are not reported. The lower reporting limit differs for each element. Reported concentrations that are below the lower reporting limit are called "left-censored." The lower reporting limit and the number of left-censored concentrations are listed in table 2. Concentrations that are just above the lower reporting limit (that is, within a multiplicative factor of approximately 10) are less precise than higher concentrations are. For example, the lower reporting limit of $\mathrm{Ce}$ is 5 milligrams per kilogram $(\mathrm{mg} / \mathrm{kg})$. Concentrations below approximately $50 \mathrm{mg} / \mathrm{kg}$ are less precise than concentrations above $50 \mathrm{mg} / \mathrm{kg}$ are. 


\subsubsection{Instrumental Neutron Activation Analysis}

Personnel at the USGS laboratory in Denver, Colorado, used instrumental neutron activation analysis (INAA) to measure the concentrations of 28 different elements. Of these 28 elements, 9 are pertinent to this study: $\mathrm{Ce}, \mathrm{Eu}, \mathrm{La}, \mathrm{Lu}, \mathrm{Nd}, \mathrm{Sm}, \mathrm{Tb}, \mathrm{Yb}$, and $\mathrm{Zr}$. These nine elements are listed in table 2. The bias and the precision of a calculated concentration in a sample depend upon the matrix in which the element is located. Hence, the lower reporting limit depends upon the sample, and there may be one or more lower reporting limits for an element. Each lower reporting limit is associated with a number of left-censored concentrations; both quantities are listed in table 2. For some elements, no reported concentrations are left-censored, so the lower reporting limit could not be established. Additional information about the measurements may be found in Hoffman (1992), Budahn and Wandless (2002), and U.S. Geological Survey (2004).

Personnel at the Becquerel Laboratories in Mississauga, Ontario, Canada, used INAA to measure the concentrations of 35 different elements. Of these 35 elements, 9 are pertinent to this study: $\mathrm{Ce}, \mathrm{Eu}, \mathrm{La}, \mathrm{Lu}, \mathrm{Nd}, \mathrm{Sm}, \mathrm{Tb}, \mathrm{Yb}$, and $\mathrm{Zr}$. The nine elements, their lower reporting limits, and the associated number of left-censored measurements are listed in table 2. Additional information about these measurements may be found in U.S. Geological Survey (2004).

\subsubsection{Discussion of Chemical Analyses}

The heavy minerals that are the focus of this investigation are refractory (section 2.1) and may be incompletely dissolved by the four acids during the ICP-AES analyses (section 3.2.2). To determine whether incomplete dissolution is a concern for this investigation, concentrations from samples measured with both ICP-AES and INAA are compared because INAA measurements are unaffected by incomplete dissolution. Both methods were used to measure $\mathrm{La}, \mathrm{Ce}$, and $\mathrm{Nd}$ (table 2), and scatterplots comparing the methods' concentrations are shown in figure 5. In each plot, the points are near the diagonal gray line, which represents equality between both measurements. If incomplete dissolution were occurring, most points would tend to be beneath the gray line, which they are not. Because La, Ce, and $\mathrm{Nd}$ partition into monazite, we infer that incomplete dissolution is not important for monazite. Therefore, we expect that the concentrations of other elements (such as Eu and $\mathrm{Sm}$ ) that partition into monazite are not affected by incomplete dissolution. Currently, we do not know whether incomplete dissolution affects the other heavy minerals (table 1). 

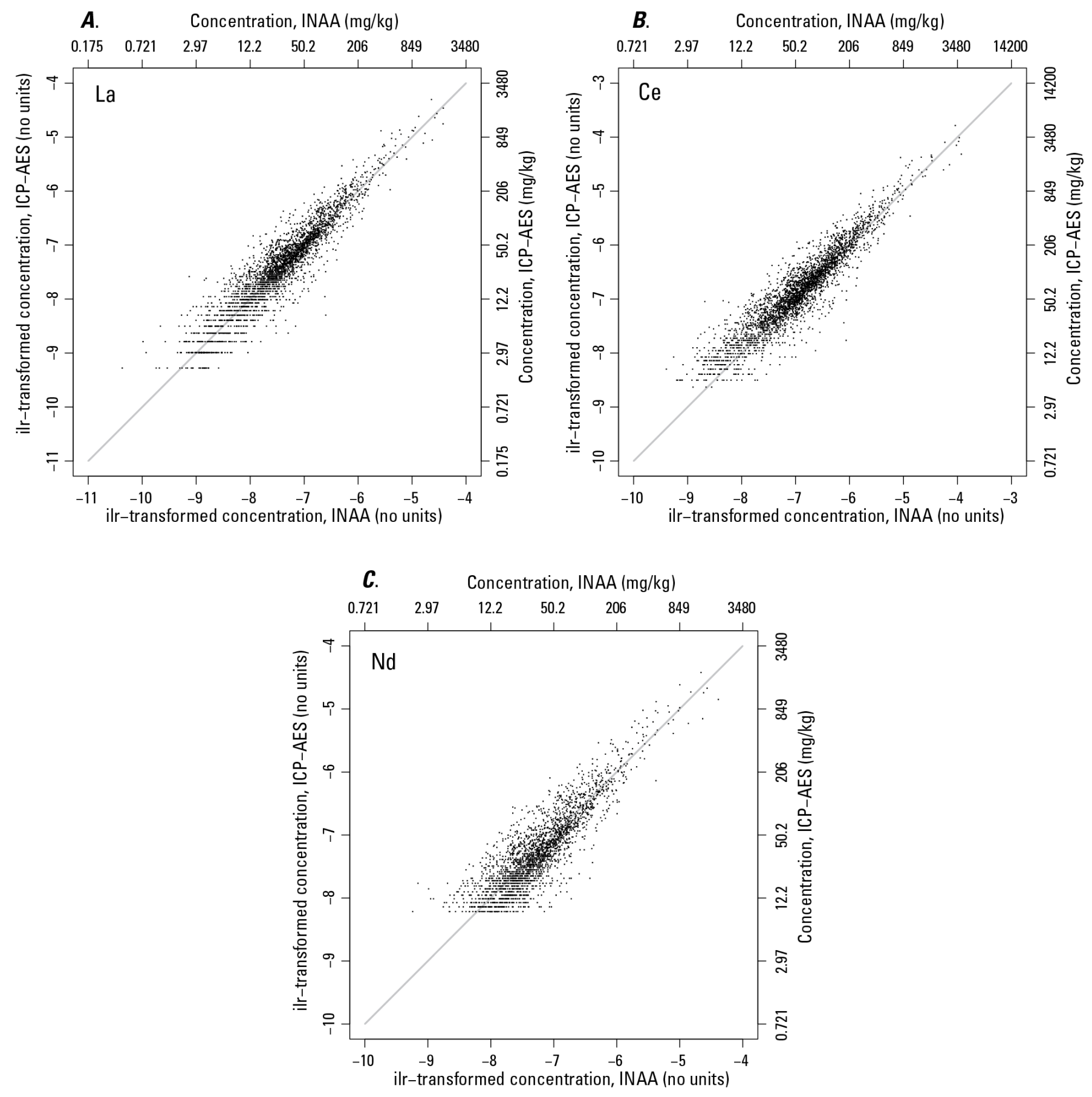

Figure 5. Scatterplots of samples measured with both ICP-AES and INAA for elements $A, \mathrm{La} ; B, \mathrm{Ce}$; and $C, \mathrm{Nd}$. The gray line represents equality between the ICP-AES and INAA measurements. Horizontal banding is caused by rounding of ICP-AES measurements to one significant digit (section 4). The lowest horizontal bands correspond to lower reporting limits. (ICP-AES, inductively coupled plasma-atomic emission spectrometry; $\mathrm{mg} / \mathrm{kg}$, milligrams per kilogram; INAA, instrumental neutron activation analysis; ilr, isometric log-ratio)

The scatterplot for Ce (figure $5 B$ ) shows that the ICP-AES concentrations tend to be slightly greater than the INAA concentrations. The cause of this difference is unknown. This difference should 
be accounted for in the integrated spatial model for $\mathrm{Ce}$, and probably in the integrated spatial models for the other elements.

The lower reporting limits for INAA measurements at the USGS laboratory and Becquerel Laboratories (table 2) show some interesting features. For all elements except Ce, the lower reporting limits for the USGS measurements are less than, equal to, or not established compared to the corresponding lower reporting limits for the Becquerel measurements. Furthermore, because the lower reporting limits for the INAA measurements depend upon the sample (section 3.2.3), the concentrations include non-censored values that are less than the lower reporting limit. For example, for $\mathrm{Nd}$ concentrations measured with INAA at the USGS laboratory, there are three non-censored concentrations that are less than or equal to the smallest lower reporting limit of $0.65 \mathrm{mg} / \mathrm{kg}$. This complication affects the calculation of quantiles (section 4.1). 
Table 2. Summary statistics for the geochemical data.

ICP-AES, inductively coupled plasma, atomic emission spectroscopy; INAA (USGS), INAA (BE), instrumental neutron activation analysis conducted at the USGS laboratory and Becquerel Laboratories, respectively; ---, lower reporting limit is not established for this set of measurements; *, censored concentration was omitted from the calculation of the order statistics; mg/kg, milligrams per kilogram; <, less than. The multiple lower reporting limits are paired with multiple numbers of left-censored concentrations.

\begin{tabular}{|c|c|c|c|c|c|c|c|}
\hline Element & $\begin{array}{l}\text { Measurement } \\
\text { method }\end{array}$ & $\begin{array}{l}\text { Number of } \\
\text { reported } \\
\text { concentrations }\end{array}$ & $\begin{array}{c}\text { Lower } \\
\text { reporting } \\
\text { limit }(\mathrm{mg} / \mathrm{kg})\end{array}$ & $\begin{array}{l}\text { Number of left- } \\
\text { censored } \\
\text { concentrations }\end{array}$ & $\begin{array}{c}0.05 \text { quantile } \\
(\mathrm{mg} / \mathrm{kg})\end{array}$ & $\begin{array}{c}0.50 \\
\text { quantile } \\
\text { (mg/kg) }\end{array}$ & $\begin{array}{c}0.95 \\
\text { quantile } \\
\text { (mg/kg) }\end{array}$ \\
\hline $\mathrm{Ce}$ & ICP-AES & 4645 & 5 & 49 & 12 & 70 & 435 \\
\hline $\mathrm{Ce}$ & $\begin{array}{l}\text { INAA } \\
\text { (USGS) }\end{array}$ & 2,775 & 6.9 & $1 *$ & 6.89 & 51.7 & 282 \\
\hline $\mathrm{Ce}$ & INAA (BE) & 404 & --- & 0 & 16 & 78 & 497 \\
\hline $\mathrm{Eu}$ & $\begin{array}{l}\text { INAA } \\
\text { (USGS) }\end{array}$ & 2,776 & --- & 0 & 0.0618 & 0.457 & 2.10 \\
\hline $\mathrm{Eu}$ & INAA (BE) & 404 & 0.5 & 154 & $<0.5$ & 0.600 & 2.49 \\
\hline $\mathrm{La}$ & ICP-AES & 4645 & 2 & 58 & 5 & 33 & 218 \\
\hline $\mathrm{La}$ & $\begin{array}{l}\text { INAA } \\
\text { (USGS) }\end{array}$ & 2,776 & --- & 0 & 3.48 & 25.0 & 140 \\
\hline $\mathrm{La}$ & INAA (BE) & 404 & 2 & 1 & 8.15 & 39.0 & 243 \\
\hline $\mathrm{Lu}$ & $\begin{array}{l}\text { INAA } \\
\text { (USGS) }\end{array}$ & 2,774 & --- & 0 & 0.086 & 0.509 & 1.630 \\
\hline $\mathrm{Lu}$ & INAA (BE) & 404 & 0.1 & 26 & $<0.1$ & 0.4 & 1.9 \\
\hline $\mathrm{Nd}$ & ICP-AES & 4645 & 9 & 728 & $<9$ & 27 & 188 \\
\hline $\mathrm{Nd}$ & $\begin{array}{l}\text { INAA } \\
\text { (USGS) }\end{array}$ & 2,776 & $\begin{array}{c}0.65,0.69 \\
8.1\end{array}$ & $1^{*}, 1^{*}, 1^{*}$ & 3.48 & 24.7 & 137 \\
\hline $\mathrm{Nd}$ & INAA (BE) & 404 & $\begin{array}{c}10,20,22 \\
24\end{array}$ & $87,1^{*}, 1^{*}, 1^{*}$ & $<10$ & 22 & 150 \\
\hline $\mathrm{Sm}$ & $\begin{array}{l}\text { INAA } \\
\text { (USGS) }\end{array}$ & 2,775 & --- & 0 & 0.658 & 4.57 & 25.0 \\
\hline $\mathrm{Sm}$ & INAA (BE) & 404 & --- & 0 & 1.40 & 6.05 & 37.8 \\
\hline $\mathrm{Tb}$ & $\begin{array}{l}\text { INAA } \\
\text { (USGS) }\end{array}$ & 2,776 & --- & 0 & 0.086 & 0.565 & 2.59 \\
\hline $\mathrm{Tb}$ & INAA (BE) & 404 & 0.5 & 128 & $<0.5$ & 0.8 & 4.1 \\
\hline $\mathrm{Ti}$ & ICP-AES & 4,645 & 50 & 0 & 1,100 & 4,100 & 8,400 \\
\hline $\mathrm{Y}$ & ICP-AES & 4,645 & 2 & 502 & $<2$ & 8 & 35 \\
\hline $\mathrm{Yb}$ & $\begin{array}{l}\text { INAA } \\
\text { (USGS) }\end{array}$ & 2,775 & --- & 0 & 0.521 & 3.06 & 9.83 \\
\hline $\mathrm{Yb}$ & INAA (BE) & 404 & 2 & 142 & $<2$ & 3.0 & 10.9 \\
\hline $\mathrm{Zr}$ & $\begin{array}{l}\text { INAA } \\
\text { (USGS) }\end{array}$ & 2,771 & --- & 0 & 198 & 1140 & 4640 \\
\hline $\mathrm{Zr}$ & INAA (BE) & 404 & 100,340 & $1,1^{*}$ & 352 & 1400 & 6300 \\
\hline
\end{tabular}




\section{Data Analysis}

\subsection{Exploratory Data Analysis}

Exploratory data analysis involves analyzing a data set, usually with simple visual methods, to discover its main characteristics (Tukey, 1977); it is prudent to perform exploratory data analysis before more sophisticated data-analysis methods (such as integrated spatial modeling) are performed. For exploratory data analysis of geochemical data, key statistics include quantiles. For this data set, the calculation of quantiles could be complicated by the non-censored concentrations that are less than the lower reporting limits (sections 3.2.3 and 3.2.4). However, because the number of such non-censored concentrations is very small, they were omitted from the calculation. This omission introduced small but negligible errors. The calculated $0.05,0.50$, and 0.95 quantiles of the concentrations are listed in table 2 . (The 0.50 quantile is the median.)

Consider, for example, the two sets of Zr measurements. The distributions for the two sets cannot be identical because their sample locations are different (fig. 4). Nonetheless, corresponding quantiles for the two sets are roughly similar (table 2), which indicates that their distributions are roughly similar. Thus, we infer that the data from the two laboratories are consistent with one another. Similar inferences pertain to the other sets of measurements.

A comprehensive analysis of all 23 sets of concentrations (table 2) would result in a very long report that would have limited value for most readers. To narrow the scope of the report, we selected four measurement sets to represent the heavy minerals. Titanium ICP-AES was chosen because it is the only available element that may be a proxy for ilmenite, rutile, and leucoxene. Likewise, $\mathrm{Zr}$ was chosen as a proxy for zircon. Of the two measurement sets for Zr, Zr INAA (USGS) was used because it has the most reported values.

The selection of an element as a proxy for monazite is more complex than it is for the previous two cases, because concentrations are available for five elements commonly found in monazite: $\mathrm{Ce}, \mathrm{Eu}$, $\mathrm{La}, \mathrm{Nd}$, and Sm. To help with the selection, pertinent concentration information is displayed in figure 6 . The five quantile maps are almost identical, indicating that the concentrations for the five elements have almost identical spatial distributions. Each of the 10 maps displaying the natural logarithm of the ratio of element concentrations shows relatively little variation across the study area, indicating that this logratio is approximately constant. Each of the 10 density plots of the log-ratio show that the spread is relatively small, again indicating that the log-ratio is approximately constant. Because the five elements are strongly associated with one another, any of the five could be selected to represent monazite. Lanthanium ICP-AES was chosen because it has the most reported values (table 2). 

La
ICP-AES
Ce
$\mathrm{Nd}$
ICP-AES
INAA (USGS)
Sm
INAA (USGS)
Eu
INAA (USGS)
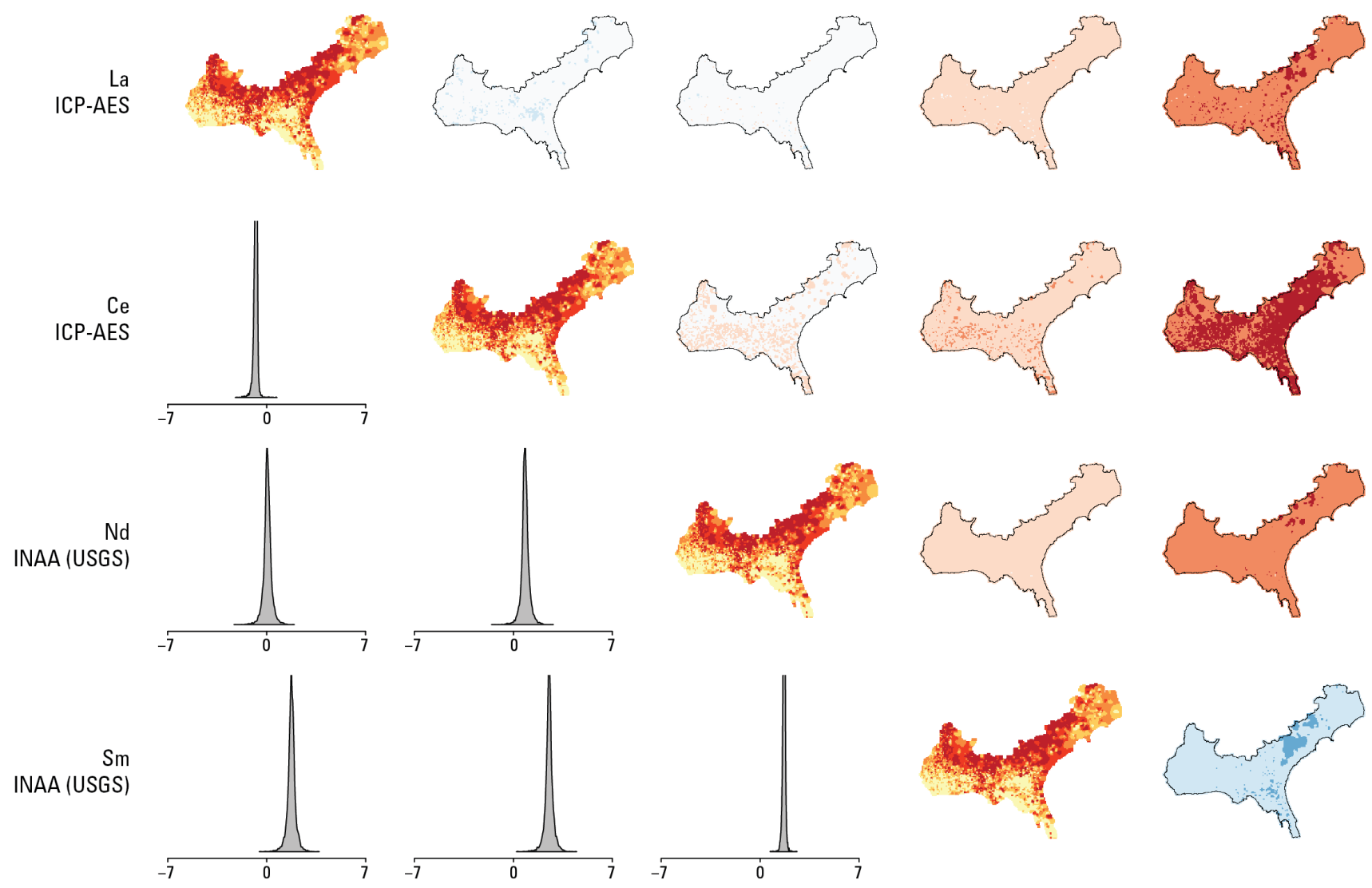

Eu
INAA (USGS)
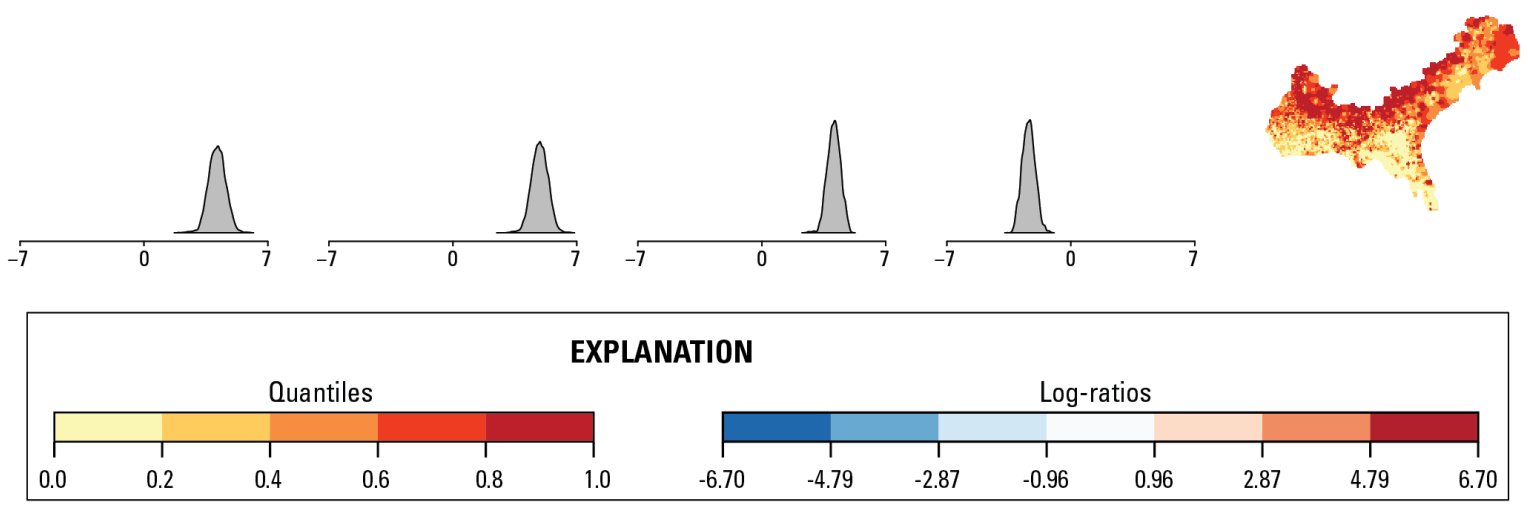

Figure 6. Associations among the element concentrations for monazite within the study area. The maps along the diagonal show concentrations of single elements by quantile. The maps above the diagonal show natural logarithms of the ratios of element concentrations. The row heading indicates the element in the numerator, and the column heading indicates the element in the denominator. For all maps, the latitudes and longitudes are omitted to increase clarity. The density plots below the diagonal show the natural logarithms of the ratios of element concentrations. In this case, the row heading indicates the element in the denominator, and the column heading indicates the element in the numerator. All vertical axes range from 0 to 2; because they are irrelevant to the analysis, they are omitted to increase clarity. (ICP-AES, inductively coupled plasma, atomic 
emission spectroscopy; INAA (USGS), INAA (BE), instrumental neutron activation analysis conducted at the USGS laboratory and Becquerel Laboratories, respectively)

The selection of an element as a proxy for xenotime is almost as complex as it is for monazite, because concentrations are available for four elements commonly found in xenotime: $\mathrm{Lu}, \mathrm{Tb}, \mathrm{Y}$, and $\mathrm{Yb}$. To help with the selection, pertinent concentration information is displayed in figure 7 . The analysis of this concentration information is the same as the analysis for monazite, so it is not repeated. The implication is that any of the four elements could be selected to represent xenotime. Yttrium ICP-AES was chosen because it has the most reported values (table 2).

Y

ICP-AES
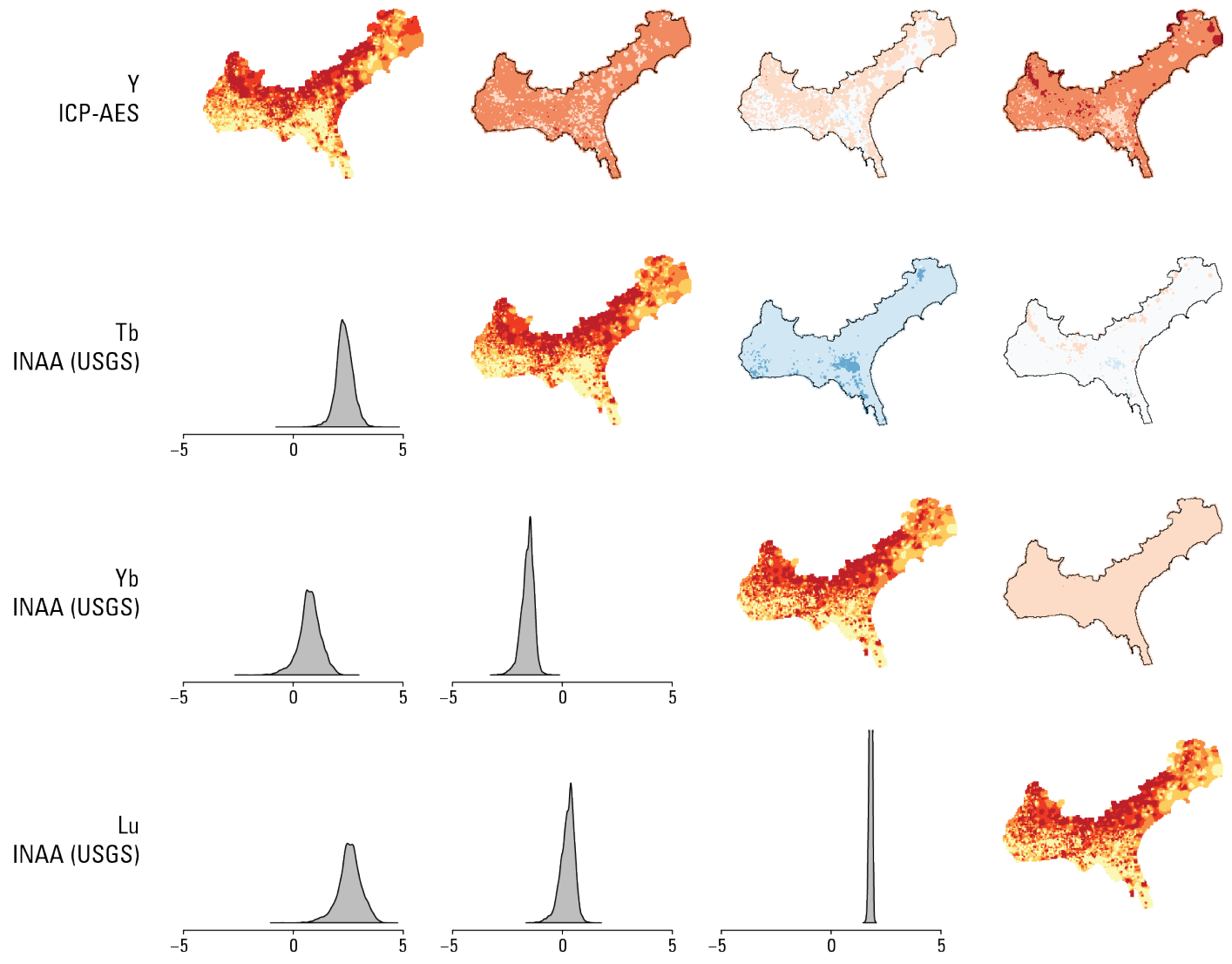

EXPLANATION
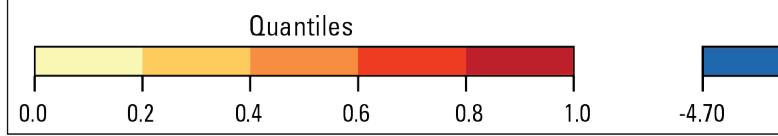

Log-ratios
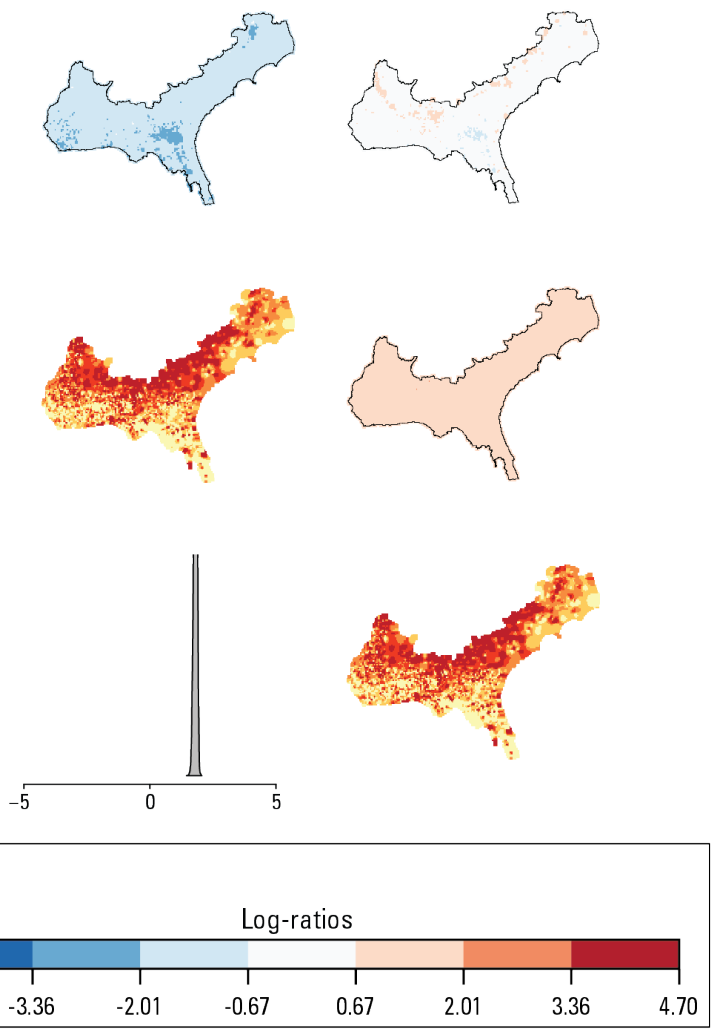

Figure 7. Associations among the element concentrations for xenotime within the study area. The maps along the diagonal show concentrations of single elements by quantile. The maps above the diagonal show natural logarithms of the ratios of element concentrations. The row heading indicates the element in the numerator, and the column heading indicates the element in the denominator. For all maps, the latitudes and longitudes are omitted to increase clarity. The density plots below the diagonal show the natural logarithms of the ratios of 
element concentrations. In this case, the row heading indicates the element in the denominator, and the column heading indicates the element in the numerator. All vertical axes range from 0 to 2; because they are irrelevant to the analysis, they are omitted to increase clarity. (ICP-AES, inductively coupled plasma, atomic emission spectroscopy; INAA (USGS), INAA (BE), instrumental neutron activation analysis conducted at the USGS laboratory and Becquerel Laboratories, respectively)

In summary, of the 23 different measurement sets listed in table 2, four are selected for further analysis: La ICP-AES, Y ICP-AES, Ti ICP-AES, and Zr INAA (USGS). These designations are awkward, so they simplified to: La, Y, Ti, and Zr. This simplification should not cause any confusion because only these four measurement sets, with one exception, are used in the rest of this report. The exception is the quantile map for $\mathrm{Zr}$ concentration, which is presented later.

Histograms for the four selected elements are shown in figure 8 . The histograms of concentrations (fig. $8 A, 8 C, 8 E$, and $8 G$ ) show that the concentrations are strongly right-skewed, especially for $\mathrm{La}, \mathrm{Y}$, and $\mathrm{Zr}$. We also analyze the concentrations after they have been transformed with the isometric log-ratio (ilr) transform (Egozcue and others, 2003) because the ilr-transformed concentrations will be used for integrated spatial modeling. The histograms of ilr-transformed concentrations (fig. $8 B, 8 D, 8 F$, and $8 H$ ) show that the ilr-transformed concentrations for $\mathrm{La}$, $\mathrm{Ti}$, and $\mathrm{Zr}$ are approximately symmetric about their respective modes, whereas the ilr-transformed concentrations for $\mathrm{Y}$ are asymmetric. 
A.

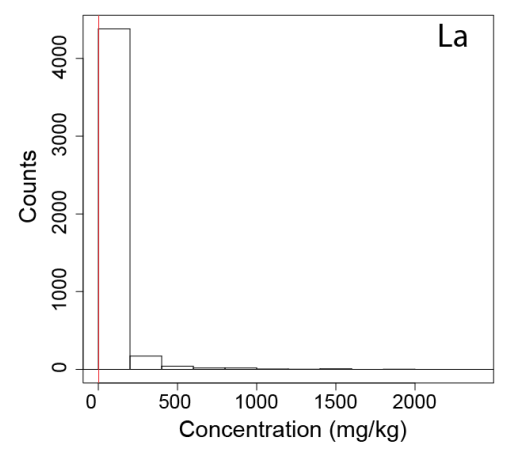

C.

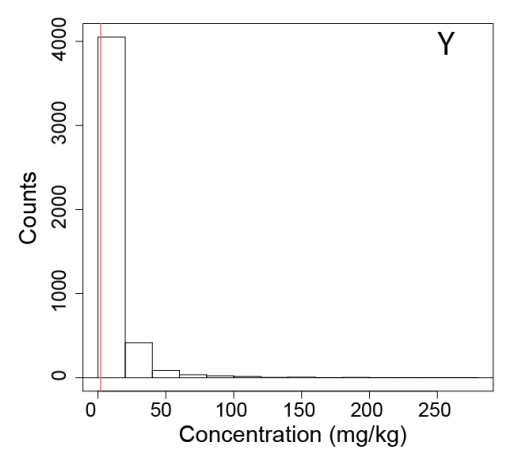

E.

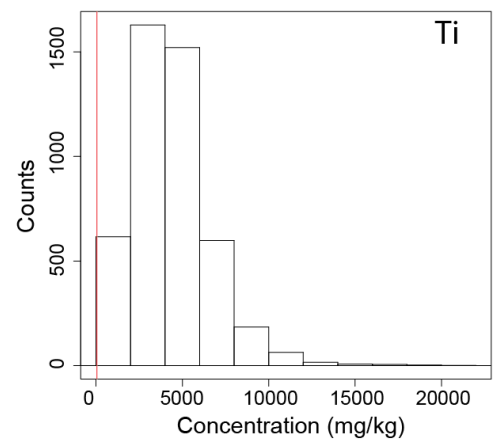

G.

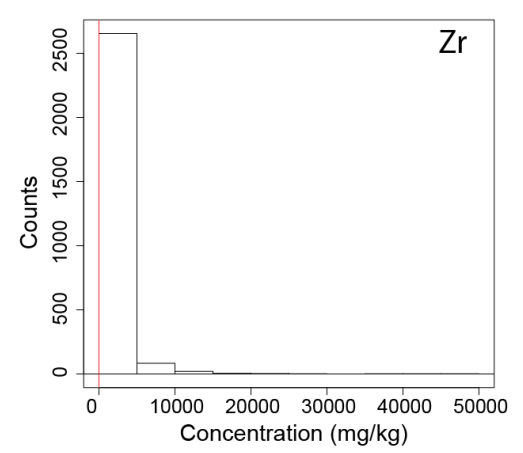

B. Concentration $(\mathrm{mg} / \mathrm{kg})$

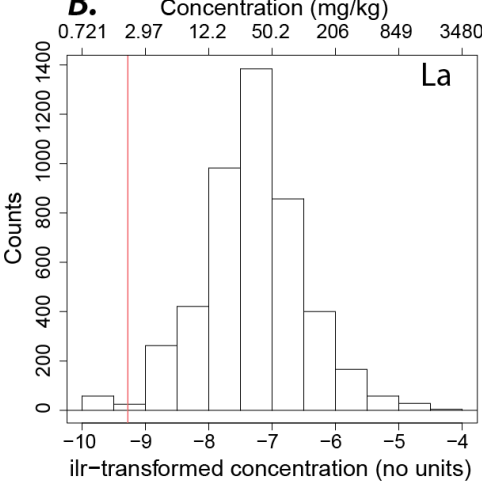

D. Concentration $(\mathrm{mg} / \mathrm{kg})$

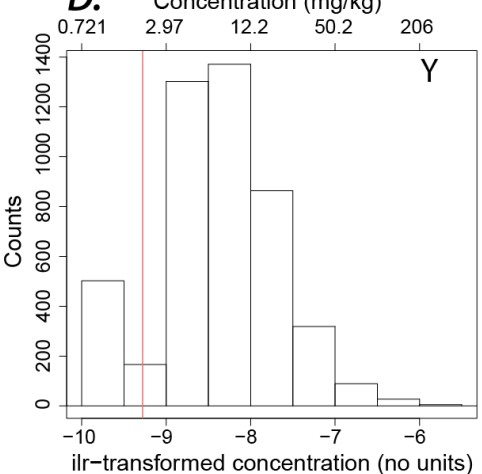

F. Concentration $(\mathrm{mg} / \mathrm{kg})$
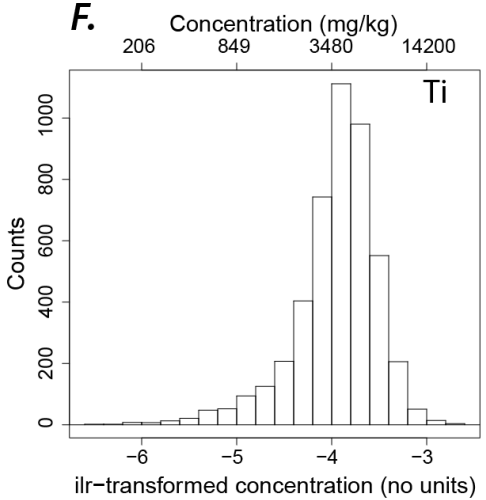

H.

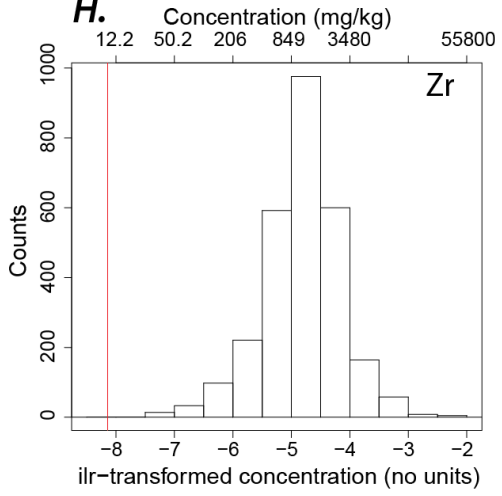

Figure 8. Histograms for $(A, B) \mathrm{La},(C, D) Y,(E, F) \mathrm{Ti}$, and $(G, H) \mathrm{Zr}$ concentrations. The histograms in $A, C, E$, and $G$ pertain to the original concentrations, whereas the histograms in $B, D, F$, and $H$ pertain to the ilrtransformed concentrations. The vertical red lines represent the lower reporting limits. Left-censored concentrations are set to one-half of the lower reporting limit for these plots. (ICP-AES, inductively coupled 
plasma, atomic emission spectroscopy; INAA (USGS), INAA (BE), instrumental neutron activation analysis conducted at the USGS laboratory and Becquerel Laboratories, respectively)

Empirical cumulative distribution functions for the four selected elements are shown in figure 9. Again, four functions pertain to the original element concentrations, whereas the other four pertain to the ilr-transformed concentrations. The four functions for the original concentrations (fig. $9 A, 9 C, 9 E$, and $9 G$ ) show that there are some relatively high concentrations. This observation is consistent with the right skew of the histograms (fig. $8 A, 8 C, 8 E$, and $8 G$ ). These high concentrations do not appear as outliers in the empirical cumulative distribution functions for the ilr-transformed concentrations (fig. $8 B$, $8 D, 8 F$, and $8 H$ ). So, we infer that the concentrations are probably unaffected by anthropogenic contamination (Reimann and others, 2008, p. 36). For all four elements, the empirical cumulative distribution functions do not show any abrupt changes in slope. So, we infer that the concentrations probably represent a single population (Reimann and others, 2008, p. 36). For La and Y, the concentrations just above the lower report limits are discrete. Here, the reported concentrations are rounded to one significant digit because the measurement error is relatively large. 
A.

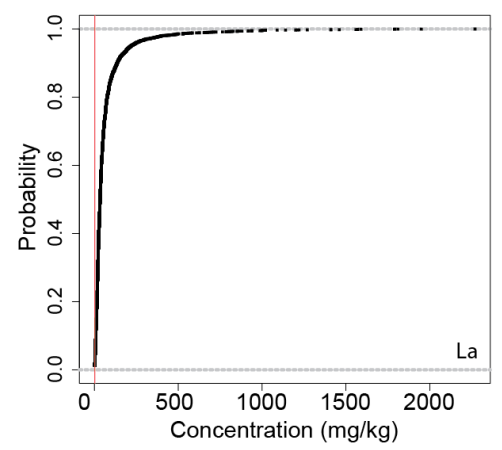

C.

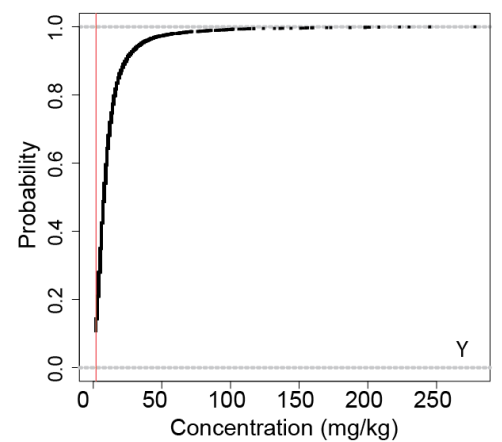

E.

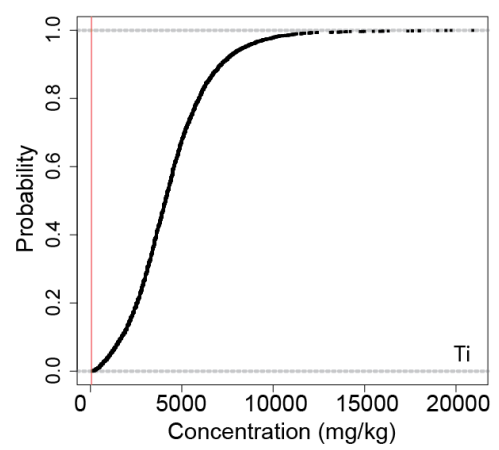

G.

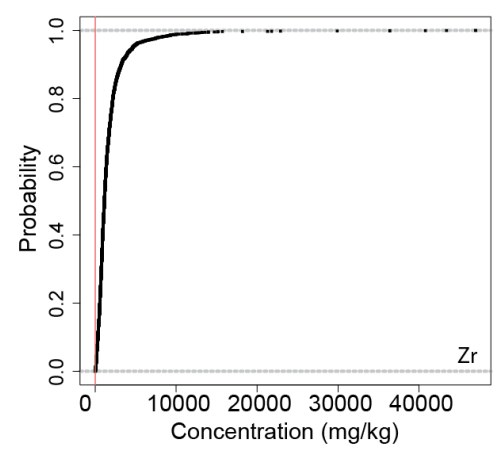

B.

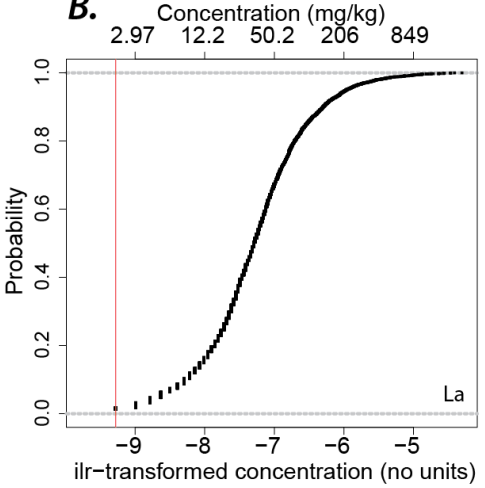

D. Concentration $(\mathrm{mg} / \mathrm{kg})$

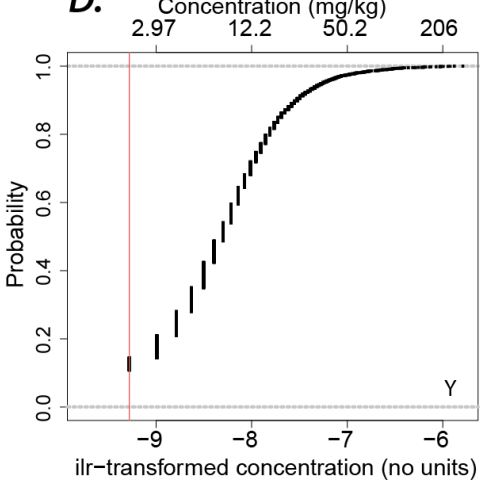

F.
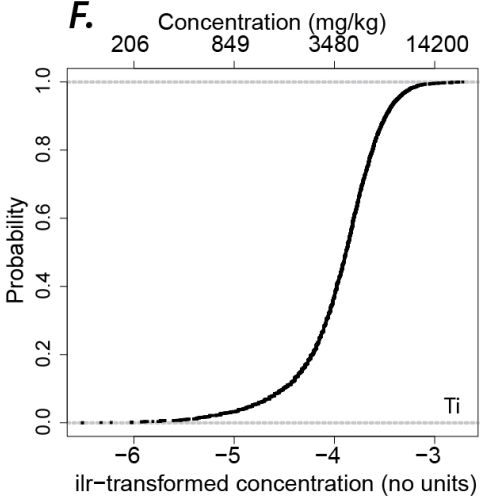

$H$.

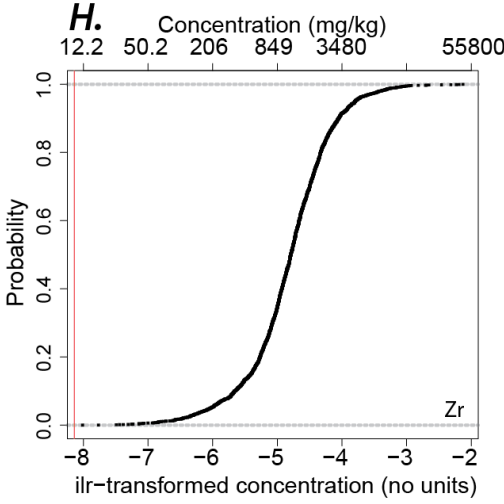

Figure 9. Empirical cumulative distribution functions for $(A, B) \mathrm{La},(C, D) \mathrm{Y},(E, F) \mathrm{Ti}$, and $(G, H) \mathrm{Zr}$ concentrations. The functions in $A, C, E$, and $G$ pertain to the original concentrations, whereas the functions in $B, D, F$, and $H$ pertain to the ilr-transformed concentrations. The vertical red lines represent the lower reporting 
limits. The horizontal gray lines are asymptotes. Values below the lower reporting limit are not plotted. ( $\mathrm{mg} / \mathrm{kg}$, milligrams per kilogram; ilr, isometric log-ratio)

Quantile maps for the four chosen elements are shown in figure 10. The maps for La and $\mathrm{Y}$ are similar, so they are described together. In the southern part of North Carolina, South Carolina, Georgia, and the eastern part of Alabama, La and Y concentrations are high near the Fall Line and decrease as the distance from the Fall Line increases except near the Atlantic coastline. The likely reason is that monazite and xenotime, eroded from Piedmont bedrock, were preferentially deposited near the Fall Line because the energy of the sediment transport system was not enough to transport the high specific gravity minerals farther. The prominent change in the northern part of North Carolina and Virginia, which occurs at the Cape Fear Arch (fig. 2), may be caused by a change in the Piedmont bedrock. The concentrations of La and $\mathrm{Y}$ are also high near the coastlines of Georgia and southeastern South Carolina; this anomaly may be associated with Pleistocene terraces that are enriched in monazite (Mertie, 1953, p. 13; Mertie, 1975, p. 11). 
A.

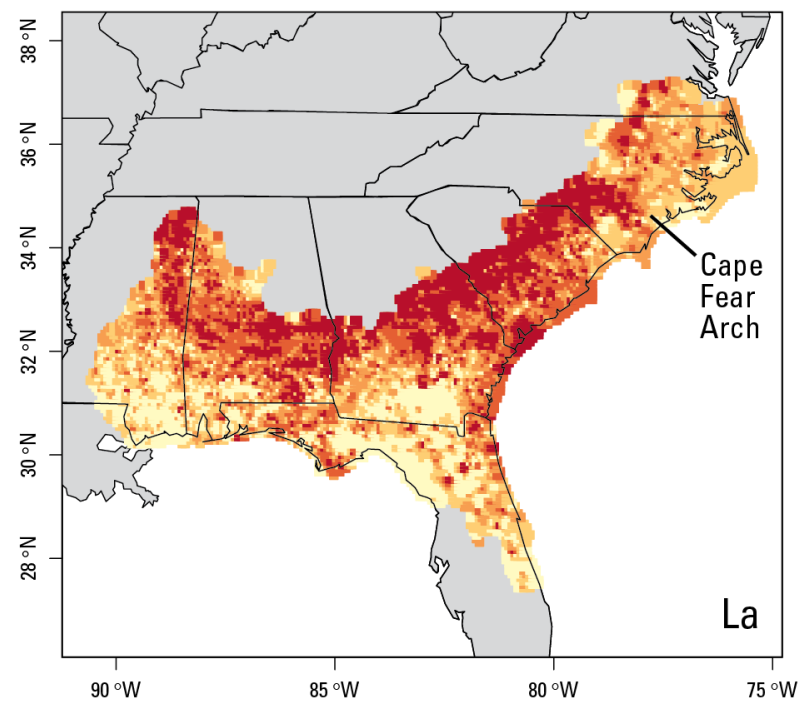

C.

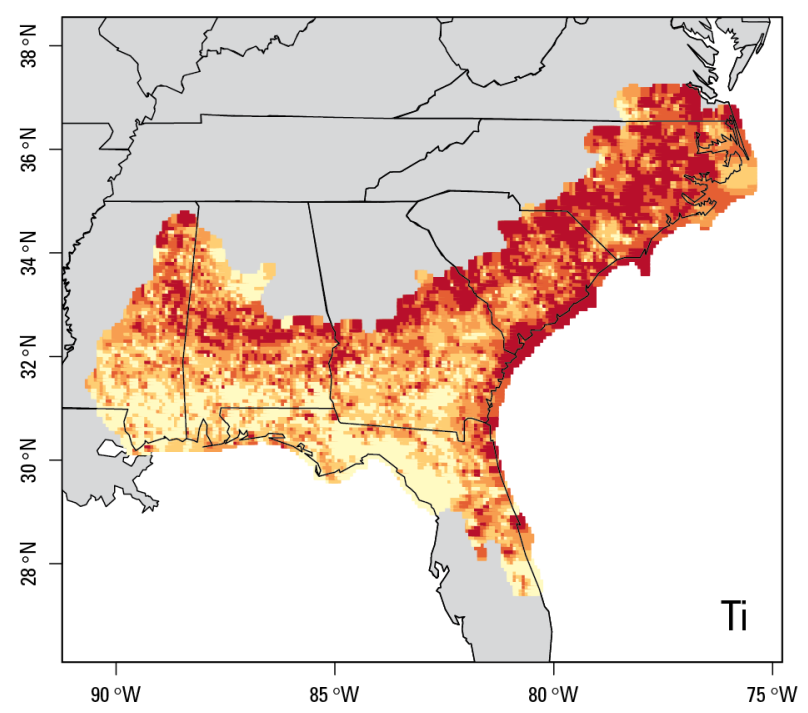

B.

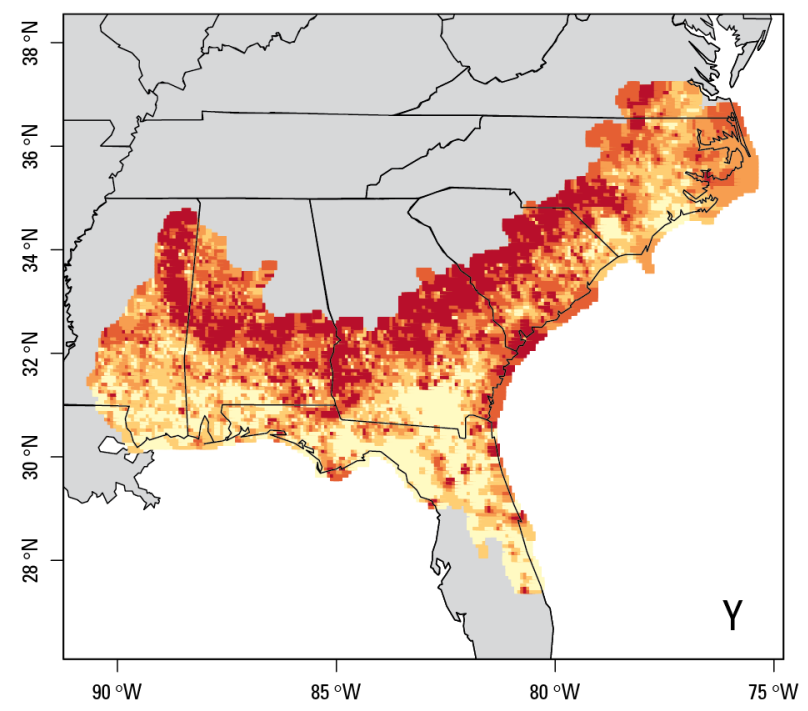

D.

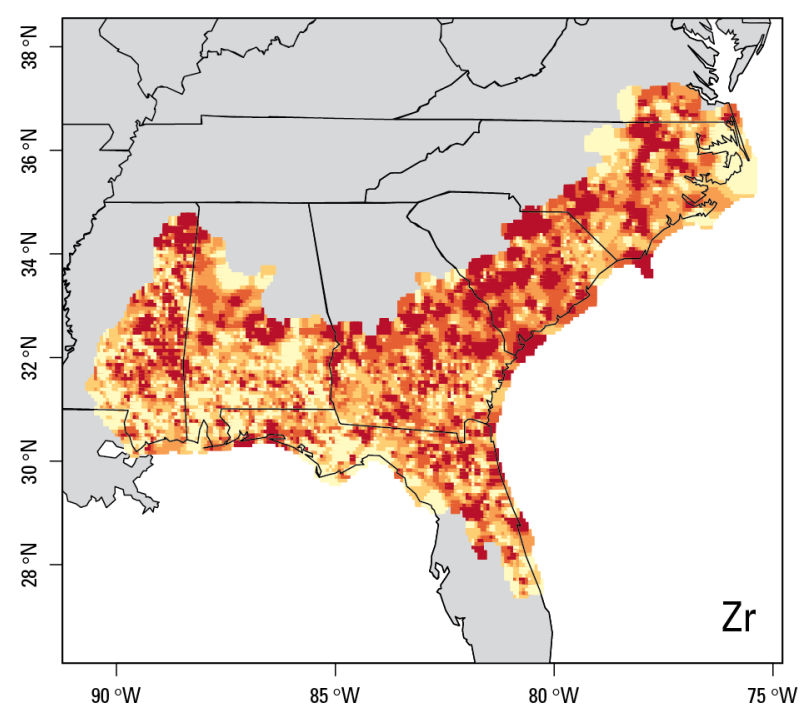

\begin{tabular}{|crrrr|}
\hline \multicolumn{5}{|c|}{ EXPLANATION } \\
Concentrations (mg/kg) \\
Quantiles & \multicolumn{1}{c|}{ La } & $\mathrm{Y}$ & $\mathrm{T}$ & $\mathrm{Zr}$ \\
-1.0 & 1830 & 213 & 19400 & 45400 \\
-0.8 & 81 & 16 & 5980 & 2280 \\
-0.6 & 44 & 10 & 4780 & 1610 \\
-0.6 & 7 & 3840 & 1220 \\
-0.4 & 28 & 4 & 2860 & 842 \\
-0.2 & 18 & 4 & 100 & 36 \\
0.0 & $<2$ & $<2$ & & \\
\hline
\end{tabular}

Figure 10. Quantile maps for $A, \mathrm{La} ; B, \mathrm{Y} ; \mathrm{C}, \mathrm{Ti}$; and $D, \mathrm{Zr}$ concentrations. (mg/kg, milligrams per kilogram)

The Ti quantile map (fig. 10C) is generally similar to the La and Y quantile maps (fig. $10 \mathrm{~A}$ and $10 B$ ), except in the northern part of North Carolina and Virginia. The similarity may be due to similar geologic processes affecting the minerals. 
The $\mathrm{Zr}$ quantile map (fig. 10D) was constructed by combining the $\mathrm{Zr}$ INAA (USGS) and $\mathrm{Zr}$ INAA (BE) measurements to make the sample density (fig. 4) closer to the sample density of the other three quantile maps. The Zr map has small-scale anomalies throughout the study area, and it lacks the regional-scale features observed in the other three quantile maps (fig. 10A,10B, and 10C). The different map patterns suggest that the geologic processes governing the distribution of $\mathrm{Zr}$ differ from those governing the distributions of the other three elements.

\subsection{Potential Explanatory Variables}

\subsubsection{Background}

The integrated spatial modeling will involve predicting the observed geochemical concentrations from other types of earth-science data, such as hydrologic, geologic, geographic, and geophysical data. These other types of data are called "explanatory variables" because they will used to explain the geochemical concentrations. Successful explanation of concentrations depends upon there being a relation between the geochemical concentrations and the explanatory variables. Investigating these relations is the focus of this section.

\subsubsection{Hydrologic Data}

Section 2.3 describes the complex geologic processes that resulted in the current distribution of the heavy minerals. One process involves alluvial transport and deposition, so it is worthwhile investigating whether the current distribution of the heavy minerals are related to the current watersheds. The current watersheds are defined in the watershed boundary data set that was developed by USGS personnel (http://water.usgs.gov/GIS/huc.html). The watersheds are hierarchical: The highest level is called a "region"; the study area is within the "South Atlantic-Gulf Region." The next level is called a "subregion"; each subregion is identified by numerical characters (for example, "01" and "14") that are specified in the watershed boundary data set. The subregions within the study area are shown in figure 11, and the analysis is based on these subregions. 


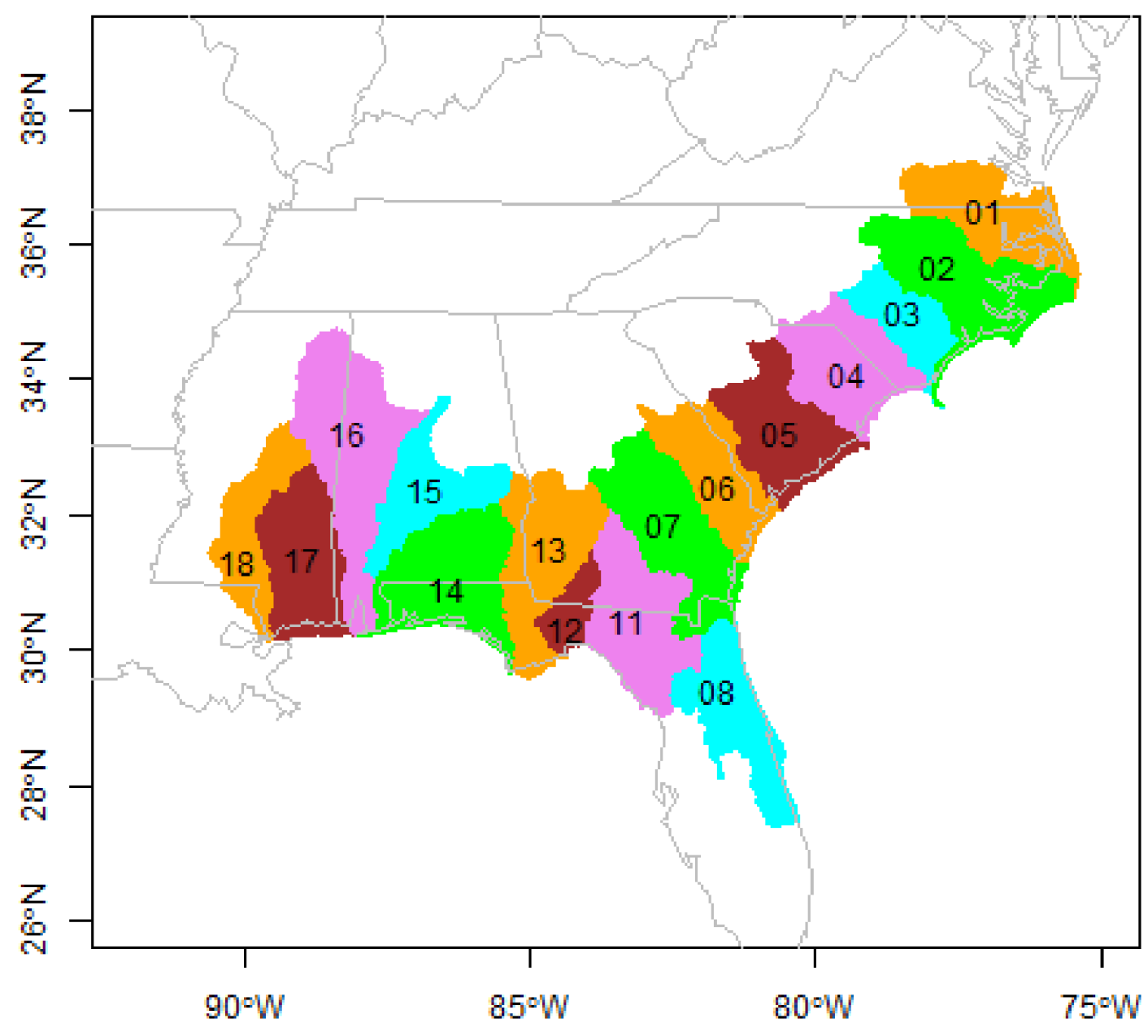

\section{EXPLANATION}

The numbered units correspond to hydrologic subregions, as defined by the U.S. Geological Survey.

Figure 11. Hydrologic subregions in the study area, as defined by the U.S. Geological Survey (http://water.usgs.gov/GIS/huc.html).

Boxplots summarizing the concentration distribution within each subregion are shown in figure $12 A, 12 B, 12 C$, and $12 D$ for $\mathrm{La}, \mathrm{Y}, \mathrm{Ti}$, and $\mathrm{Zr}$, respectively. The boxplots are arranged according to the geographic locations of the subregions: The first 10 boxplots (namely, from 16 to 01 ) correspond to the 10 subregions that adjoin the Piedmont, and the boxplots are ordered from southwest to northeast. The next 6 boxplots (namely, from 18 to 08 ) correspond to the 6 subregions that do not adjoin the Piedmont, and the boxplots are ordered from west to east. 
A.
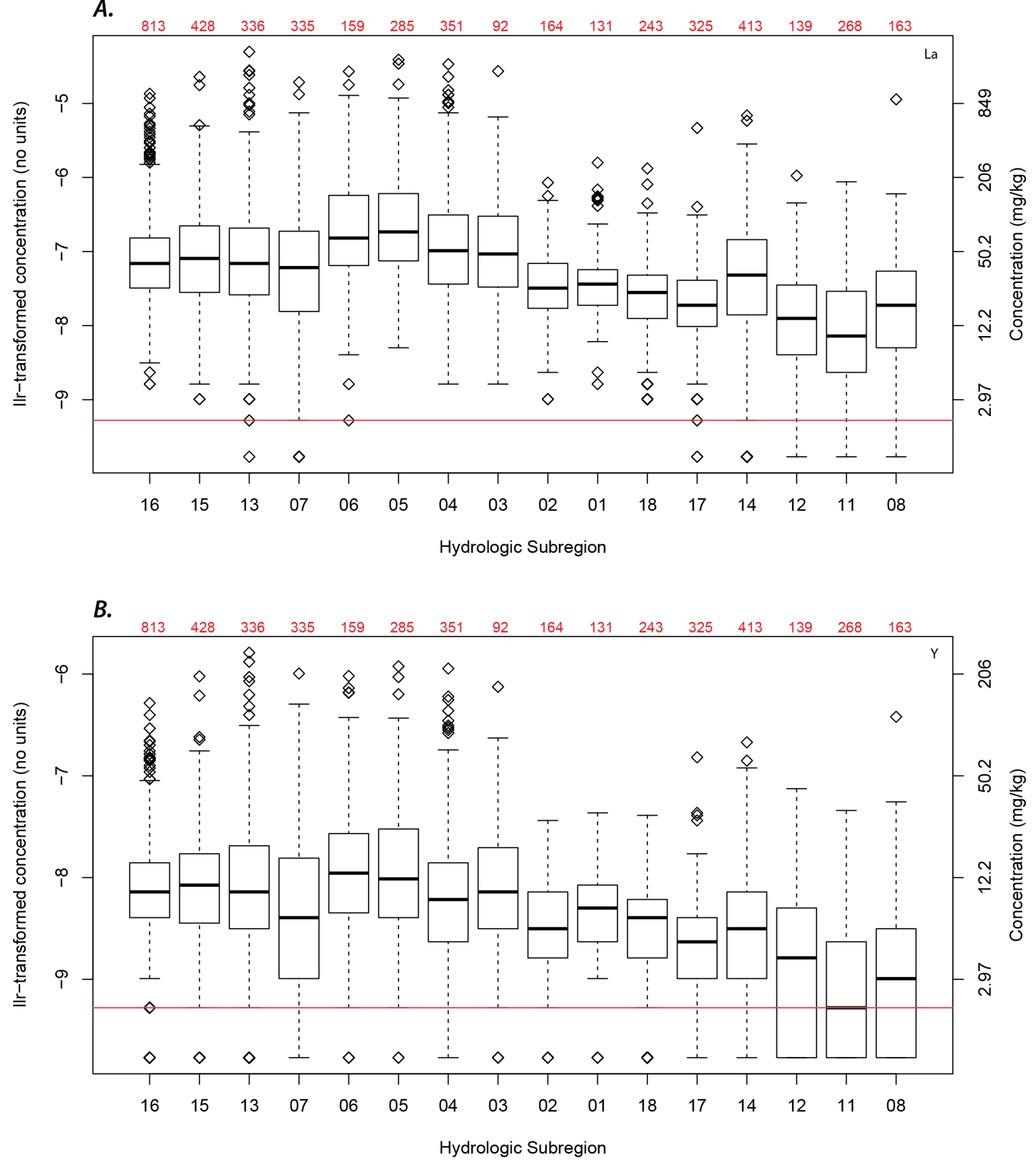

Figure 12. Boxplots of ilr-transformed concentrations of $A, \mathrm{La} ; B, Y ; C, \mathrm{Ti}$; and $D, \mathrm{Zr}$. The concentrations are categorized by their hydrologic subregion (fig. 11). The red numbers are the number of samples taken per subregion. The horizontal red lines represent the lower reporting limits. Left-censored values are set to one-half of the lower reporting limit for this plot. (mg/kg, milligrams per kilogram; ilr, isometric log-ratio) 

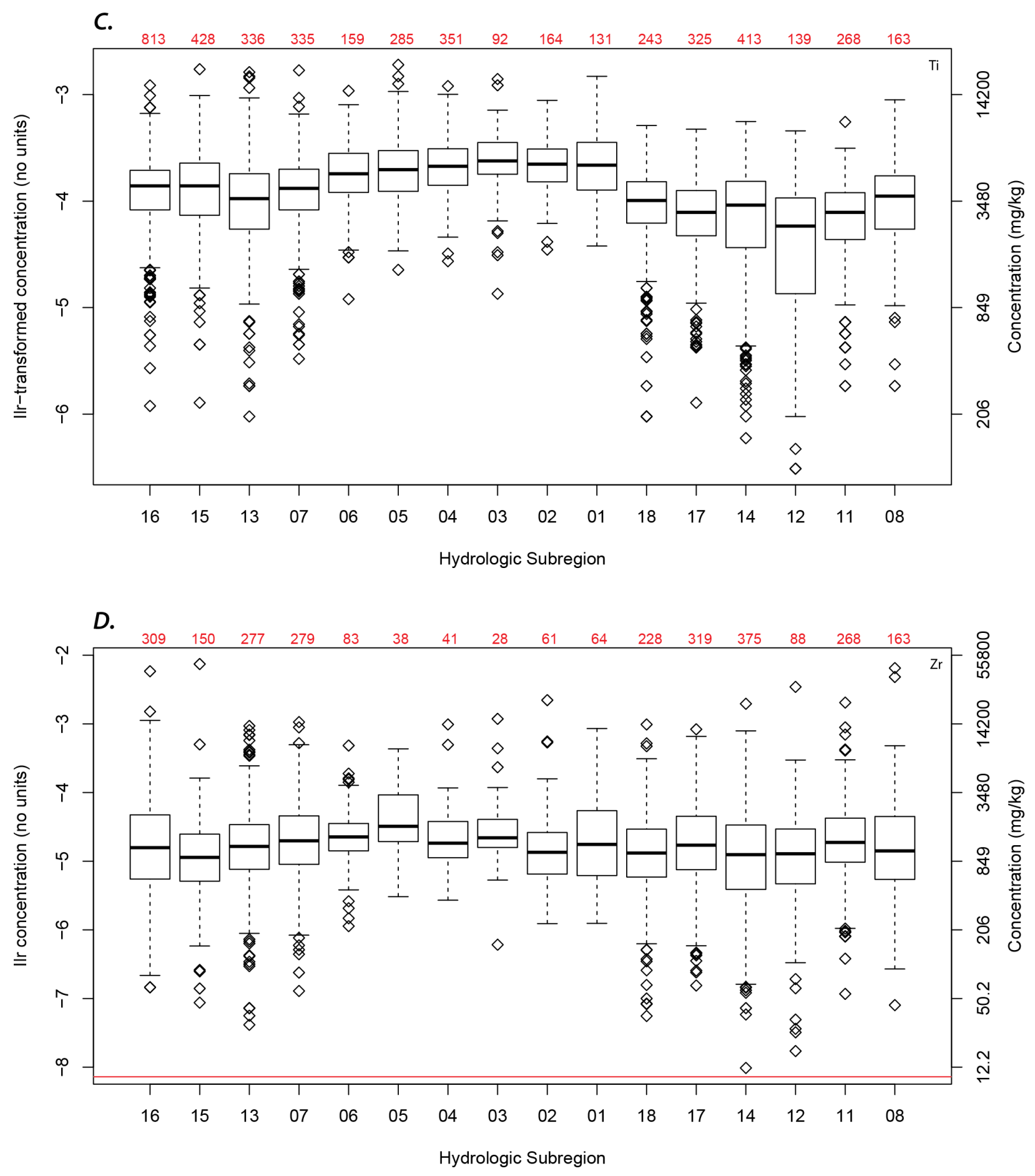

Figure 12. Boxplots of ilr-transformed concentrations of $A, \mathrm{La} ; B, Y ; C, \mathrm{Ti}$; and $D, \mathrm{Zr}$. The concentrations are categorized by their hydrologic subregion (fig. 11). The red numbers are the number of samples taken per subregion. The horizontal red lines represent the lower reporting limits. Left-censored values are set to one-half of the lower reporting limit for this plot. (mg/kg, milligrams per kilogram; ilr, isometric log-ratio)—Continued 
The boxplots for La and Y (fig. $12 A$ and $12 B$ ) show that the highest element concentrations tend to be in subregions 16 to 03 . This finding is expected because these eight subregions adjoin the Piedmont and also because subregions 07 to 04 include the Pleistocene terraces along the Atlantic coastline (Mertie, 1953, p. 13; Mertie, 1975, p. 11). The remaining subregions (namely, 02, 01, and 18 to 08 ) generally have lower concentrations. The boxplots for $\mathrm{Ti}$ (fig. 12C) show that the highest concentrations tend to be in subregions 16 to 01 . The most significant difference from La and $\mathrm{Y}$ involves subregions 02 and 01: Here, the concentrations of the Ti are relatively high, whereas the concentrations of La and $\mathrm{Y}$ are relatively low. This difference may be caused by differences in the Piedmont bedrock. The boxplots for $\mathrm{Zr}$ (fig. 12D) show that the medians and interquartile ranges are roughly the same for all subregions. All of these findings are consistent with the patterns observed in the quantile maps (fig. 10).

These findings indicate that there are large-scale trends in the distributions of La, Y, and $\mathrm{Ti}$ (but not $\mathrm{Zr}$ ). It is tempting to conclude that these large-scale trends are caused by fluvial processes within the current watersheds, but this conclusion may be incorrect. For example, the large-scale trends may be caused by regional geologic processes, such as longshore transport, which has been well documented in Australian deposits (Force, 1991). Whatever the cause, these findings indicate that large-scale trends will be important in spatial modeling.

\subsubsection{Geographic Data}

The major source of the heavy minerals is the Piedmont (section 2.3), so it is reasonable to assume that concentration depends upon the distance from the Fall Line. Indeed, this relation is apparent in the quantile maps for $\mathrm{La}, \mathrm{Y}$, and $\mathrm{Ti}$ (fig. 10). To investigate this relation in greater detail, the distance from each sample location to the Fall Line was calculated. Because the Fall Line is defined by many closely spaced points, the distances from the sample location to the Fall Line points vary, and only the minimum distance is used for this investigation. Scatterplots of ilr-transformed concentration versus minimum distance are shown in figure 13. The scatterplots omit the few points with concentrations below the lower reporting limit, and these omissions have no significant effect on this analysis. For all four elements (fig. 13), the straight lines fit to scatterplot data have negative slopes; even the 95-percent confidence intervals for these straight lines have negative slopes. The large negative slopes for La, Y, and $\mathrm{Ti}$ are consistent with the hypothesized relation regarding distance from the Fall Line. In contrast, the small negative slope for $\mathrm{Zr}$ is barely consistent with this hypothesized relation. Indeed, this result for $\mathrm{Zr}$ is expected because the quantile map does not show any obvious relation between concentration and distance (fig. 10D). 
A.

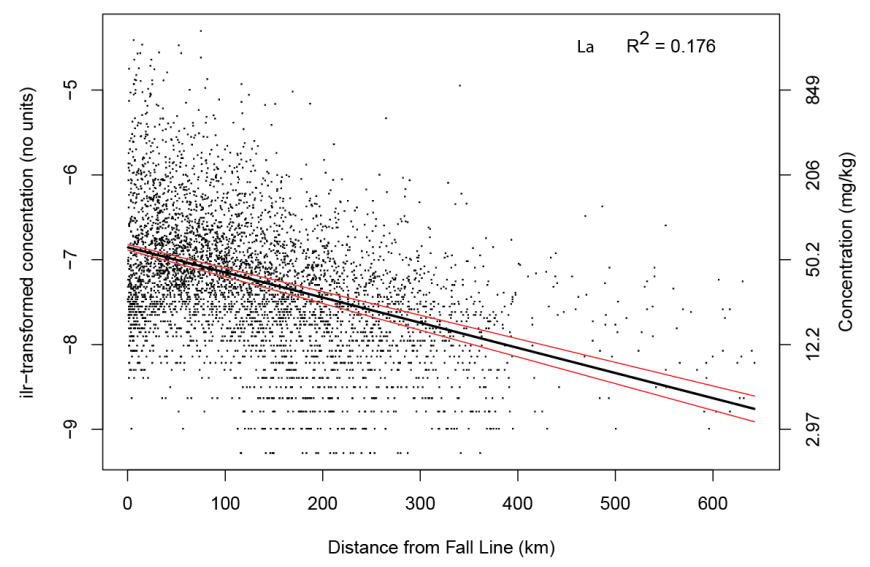

C.

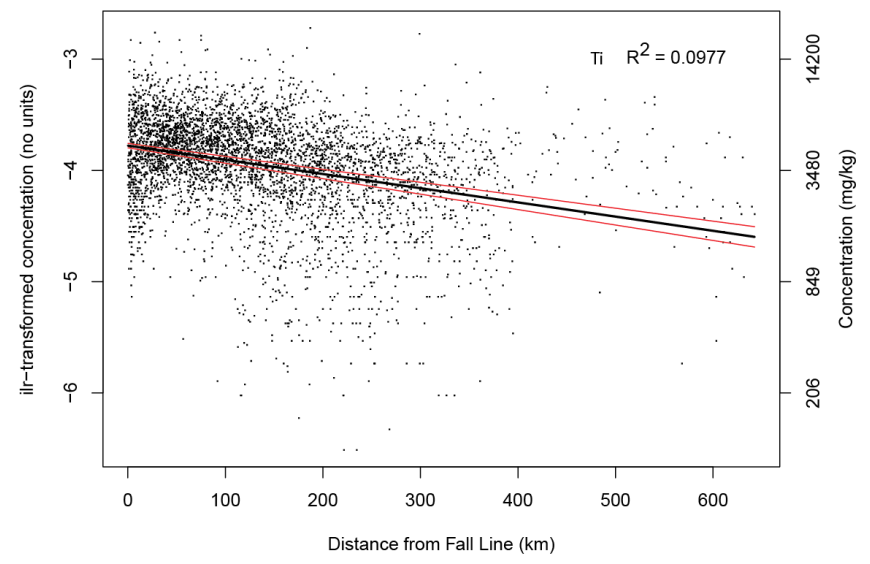

B.

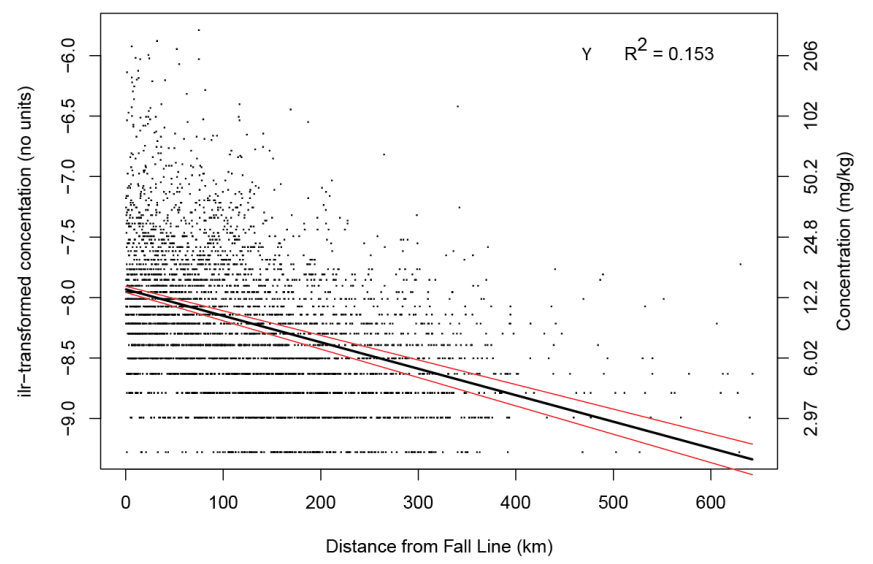

$D$.

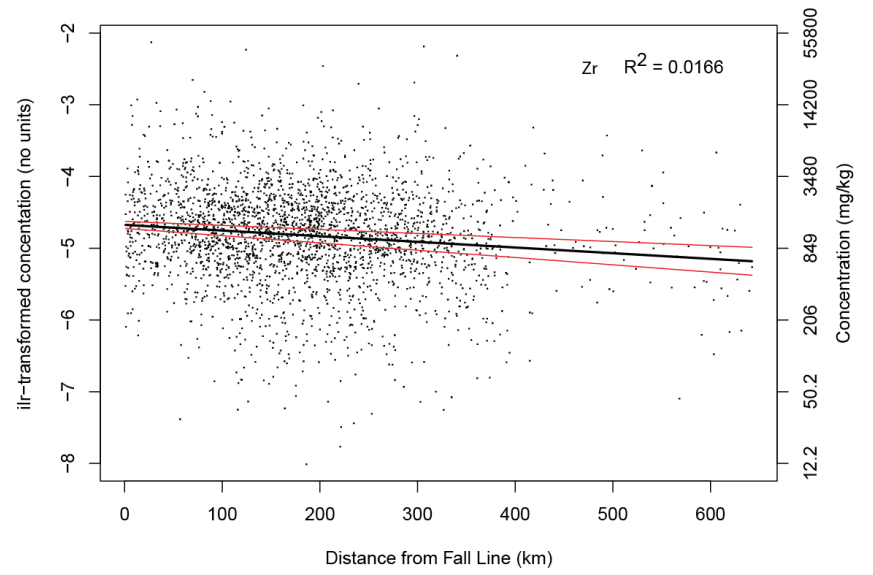

Figure 13. Scatterplots showing that the ilr-transformed concentration depends on distance from the Fall Line for $A$, La; $B, Y ; C, T i$; and $D, Z r$. The black solid lines represents the best-fitting straight line to the data; the associated red dashed lines represent the 95-percent confidence interval due uncertainty in the slope and intercept parameters. The horizontal banding is due to rounding of the reported concentration to one significant digit. The lowest horizontal bands correspond to lower reporting limits. Parameter $\mathrm{R}^{2}$ is the proportion of the variance in the data that is explained by straight line. ( $\mathrm{mg} / \mathrm{kg}$, milligrams per kilogram; ilr, isometric log-ratio)

All four scatterplots (fig. 13) show that the ilr-transformed concentrations are widely scattered about the best-fitting straight lines. The proportion of the variance explained by the linear regression $R^{2}$ is $0.176,0.153$, and 0.098 for $\mathrm{La}, \mathrm{Y}$, and $\mathrm{Ti}$, respectively. That is, distance from the Fall Line explains only a small proportion of the variation in the data. Because the proportions are small, it is tempting to dismiss the regressions and hence to dismiss the distance from the Fall Line as an explanatory variable. We believe that such action would be a mistake. We believe that the small proportions are indicative of other geologic processes that are not taken into account in the regression: The high concentrations along the coasts of South Carolina, Georgia, and northeastern Florida may be associated with Pleistocene terraces, and the low concentrations of $\mathrm{La}$ and $\mathrm{Y}$ in the northern part of North Carolina and Virginia may be caused by a change in the mineralogy of the Piedmont. Future work should account for these other geologic processes. 
For $\mathrm{Zr}$, the proportion of the variance explained by the linear regression $R^{2}$ is 0.02 (fig. $13 D$ ). That is, distance from the fall line explains practically none of the variation in the data. This result is expected because the spatial distribution of $\mathrm{Zr}$ (fig. 10D) lacks regional-scale features.

\subsubsection{Airborne Radiometric Data}

The National Uranium Resource Evaluation program was initiated in 1973 with a primary goal of identifying uranium resources within the United States. As part of this program, airborne radiometric data were collected in the conterminous United States and Alaska (Hill and others, 2009). These data are measurements of the spectra of gamma-ray radiation, which are processed to yield estimates of the relative concentrations of $\mathrm{U}, \mathrm{Th}$, and $\mathrm{K}$. These estimated concentrations pertain to a layer at ground level, and its thickness depends upon properties such as water content (Gregory, 1960, p. 11-15). Within the study area, the maximum thickness is assumed to be less than $1.5 \mathrm{~m}$. The airborne survey lines were generally oriented east-west, and the spacing between the survey lines ranged from 1.6 to $10 \mathrm{~km}$. Tie lines were oriented perpendicular to the survey lines, and the spacing between the tie lines ranged from 16 to $30 \mathrm{~km}$. To collect these data, the airplane or helicopter was approximately $122 \mathrm{~m}$ above ground. Additional information about the data collection and processing is available in Duval (1990, 1999). Background information about airborne radiometric surveys is available in Gregory (1960), Moxham (1960), Bates (1962), and Pitkin (1968).

Both monazite and xenotime include Th in their crystal structures (section 2.1), so airborne radiometric equivalent Th concentrations may be related to La and $\mathrm{Y}$ concentrations. Because of the similarity among the quantile maps for $\mathrm{La}, \mathrm{Y}$, and $\mathrm{Ti}$ (fig. $10 \mathrm{~A}, 10 \mathrm{~B}$, and $10 \mathrm{C}$ ), airborne radiometric equivalent Th concentrations may also be an explanatory variable for Ti concentrations. Consequently, this section focuses on only the airborne radiometric equivalent Th concentration, not the associated airborne radiometric $\mathrm{U}$ and $\mathrm{K}$ concentration. To simplify the terminology, airborne radiometric equivalent Th concentration is referred to as just eTh concentration.

The survey and tie lines of the airborne survey that are within the study area are shown in figure 14. There are four, moderately large areas without any survey or tie lines: Eglin Air Force Base in the

panhandle of Florida, Fort Stewart in southeastern Georgia, Savannah River Site in South Carolina, and Fort Bragg in North Carolina (fig. 2). The data along these survey and tie lines consist of 1,507,617 eTh concentrations. 




Figure 14. Survey and tie lines of the airborne radiometric survey that are within the study area. The green polygon represents the border of the study area.

Of the 1,507,617 reported concentrations, 45,490 concentrations are 0 parts per million (ppm). The non-zero, reported concentrations range from 0.055 to $708.7 \mathrm{ppm}$, and the median is $4.3 \mathrm{ppm}$. The histogram of the concentrations (fig. 15A) is severely right-skewed. The histogram of the ilrtransformed concentrations (fig. 15B) is right-skewed, but to a lesser degree. So, the ilr-transformed concentrations are not normally distributed. 
A.

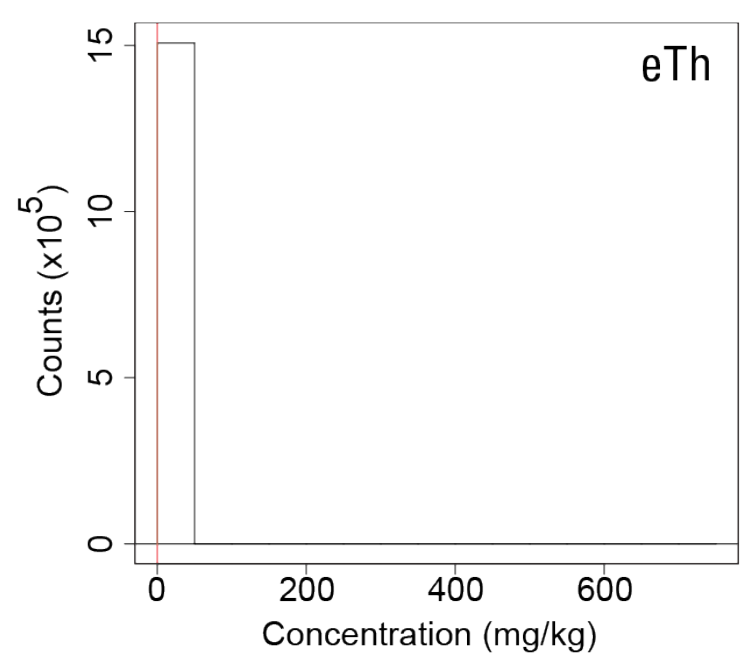

B. Concentration $(\mathrm{mg} / \mathrm{kg})$

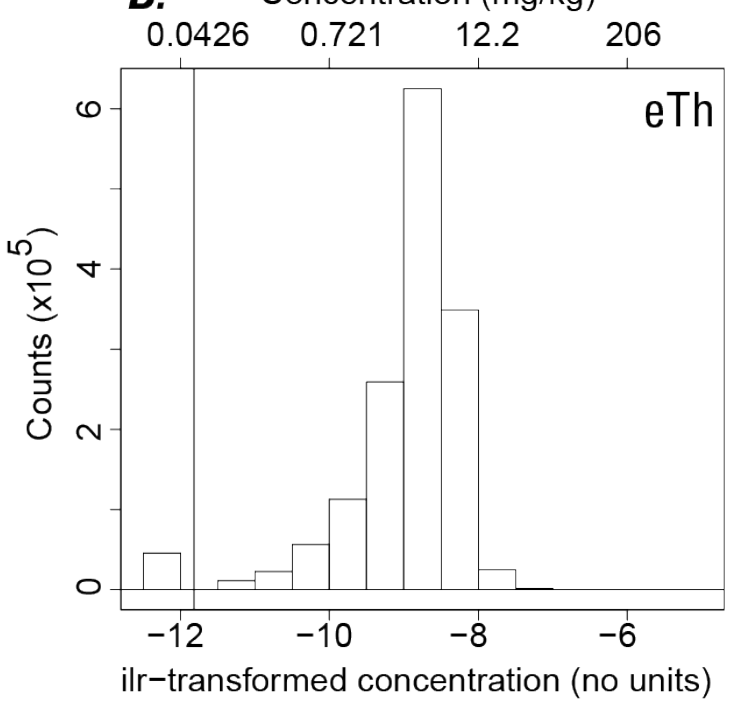

Figure 15. Histograms of equivalent thorium (eTi) concentrations from the airborne radiometric survey. The vertical red line represents the smallest non-zero concentration, 0.055 parts per million (ppm). Zero-valued concentrations are set to $0.0275 \mathrm{ppm}$, which is half of the lowest reported concentration. (mg/kg, milligrams per kilogram; ir, isometric log-ratio)

Equivalent thorium concentrations along a 22-km, east-west survey line near the coast of North Carolina are shown in figure 16. This transect shows that zero-valued concentrations occur where other nearby concentrations are low. We infer that these zero-valued concentrations are useful information because they are indicative of low-valued concentrations.

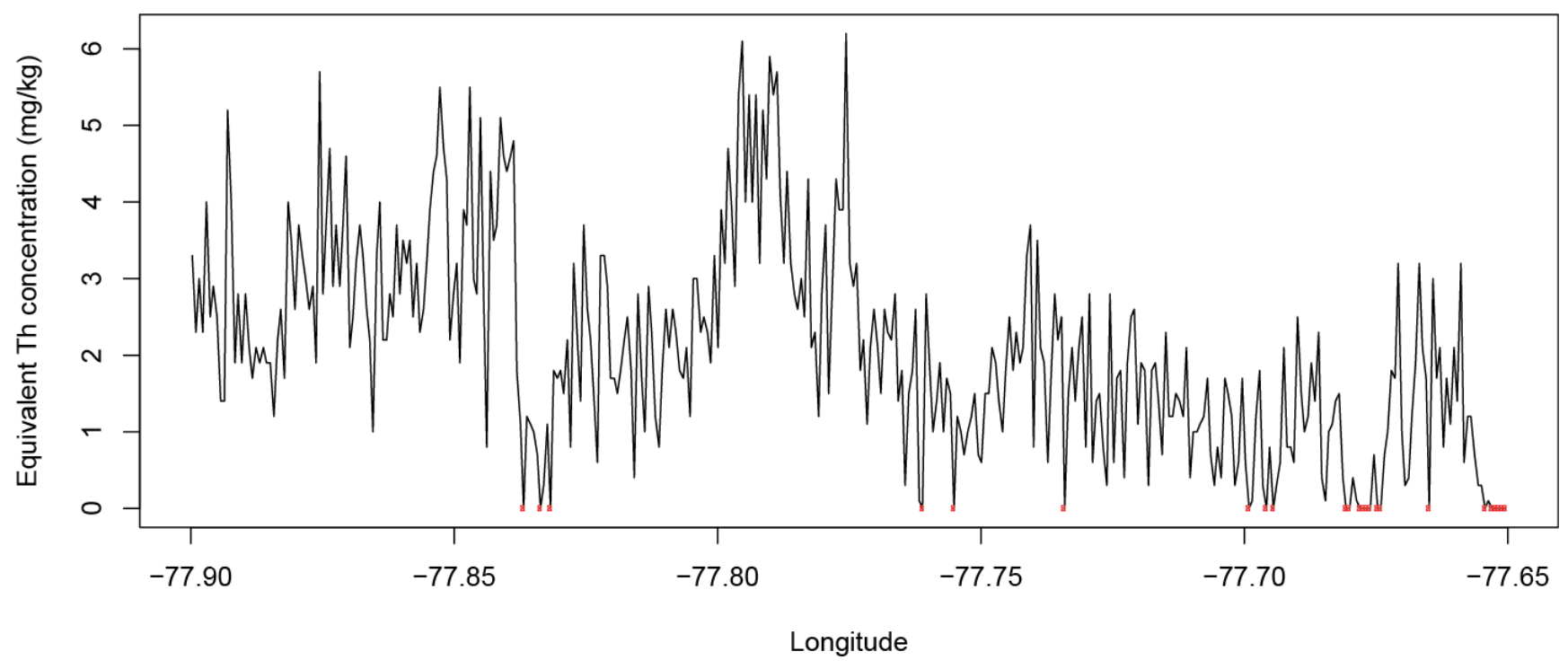

Figure 16. Equivalent thorium (eTh) concentrations along a survey line near the coast of North Carolina. The red dots represent zero-valued concentrations. (mg/kg; milligrams per kilogram) 
A quantile map of eTh concentrations was constructed using all reported concentrations, including the zero-valued concentrations (fig. 17). High to moderately high concentrations are found near the Fall Line, except in northwest Alabama and northeastern Mississippi where the high concentrations are offset from the Fall Line. A thin line of high concentration occurs near the Georgia coast. Another thin line extends from central Mississippi into southern Alabama and may be associated with the coastline during the Oligocene or Miocene (Galloway and others, 2001).

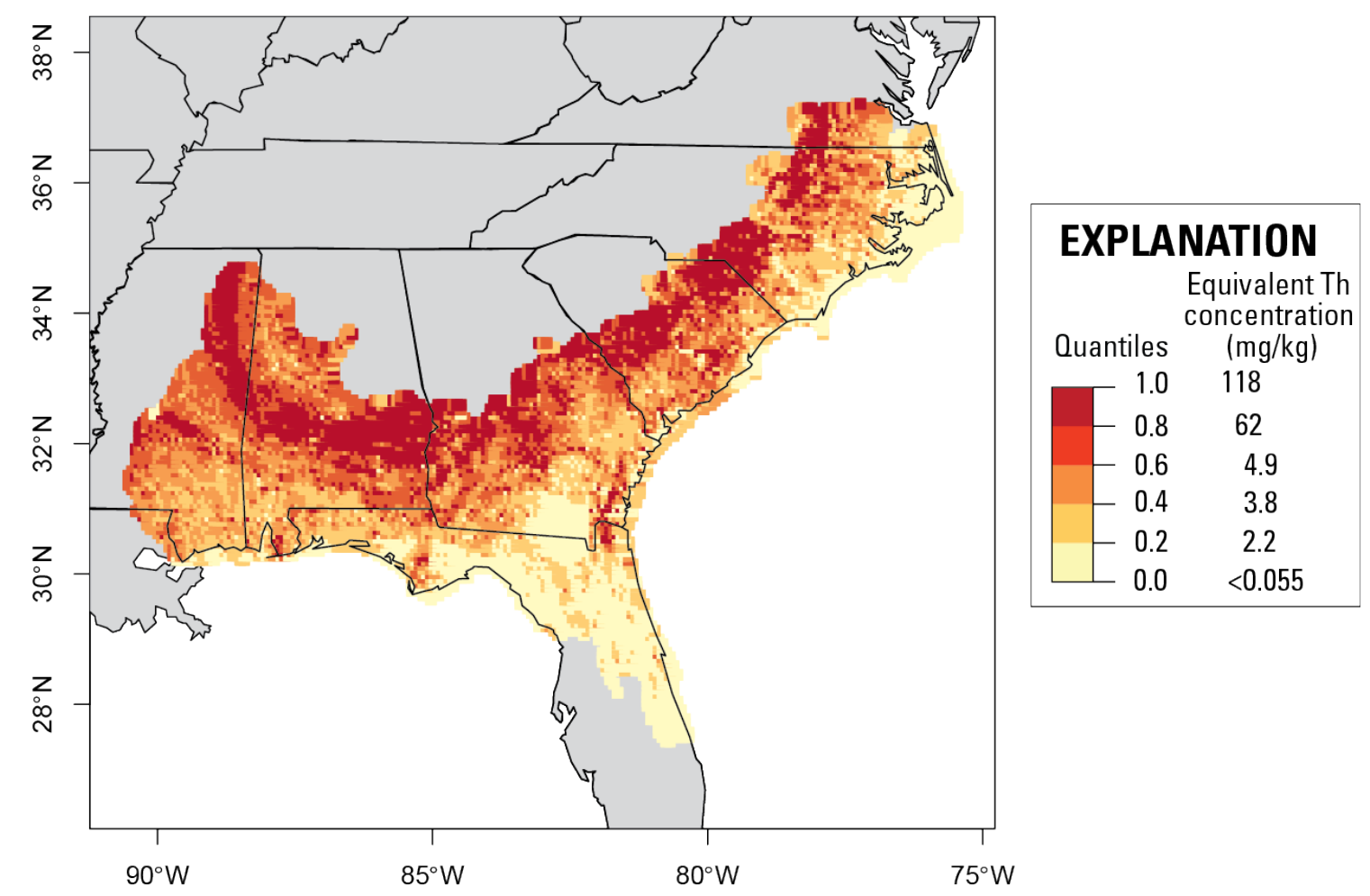

Figure 17. Quantile map of equivalent thorium (eTh) concentrations.

The quantile map of eTh concentrations (fig. 17) is similar to the quantile maps of La and Y concentrations (fig. 10A and 10B). This similarity is expected because both monazite and xenotime contain thorium (section 2.1). The eTh quantile map also is somewhat similar to the Ti quantile map (fig. 10C), presumably because monazite, xenotime, ilmenite, rutile, and leucoxene have undergone somewhat similar geologic processes. In contrast, the eTh quantile map differs significantly from the $\mathrm{Zr}$ quantile map (fig. 10D), presumably because zirconium has undergone different geologic processes.

The eTh concentrations are a type of compositional data, so it seems that they should be transformed with the isometric log-ratio transformation to make scatterplots and to perform further analyses. However, this transformation will not work because of the zero-valued concentrations. So, another transformation is needed, and it must satisfy three criteria: First, it must transform both the zerovalued and non-zero-valued concentrations. The zero-valued concentrations should be included in the scatterplots because these concentrations contain information. Second, the transformation should be continuous, mapping the continuous eTh concentrations onto a continuous transformed quantity. To understand the importance of this criterion, consider the alternative: discretizing the continuous Th concentrations. This alternative is undesirable because it eliminates information. Third, the transformed 
quantity must be a real-valued number on the interval $(-\infty, \infty)$ so that standard statistical methods can be used to analyze the transformed quantities.

The chosen transformation is the normal scores transformation, which is usually used for spatial data (Schabenberger and Gotway, 2005, p. 271). The essential idea of this transformation is to map the quantiles of the eTh concentration onto quantiles of a standard normal distribution, which are called the "normal scores." To prevent equal eTh concentrations from being mapped to the same quantile of the standard normal distribution, the equal concentrations are randomly perturbed. The calculated transformation (fig. 18) is monotonically increasing and is non-linear. All zero-valued concentrations were assigned a small positive value (namely $0.0275 \mathrm{mg} / \mathrm{kg}$, which is half of the smallest reported value) so that they could be plotted on the logarithmic horizontal axis of figure 18 . These zero-valued concentrations are represented by the vertical set of points that are less than -2 along the vertical axis. The normal scores may be interpreted as an indicator of eTh concentrations: Low, moderate, and high normal scores correspond to low, moderate, and high eTh concentrations, respectively.

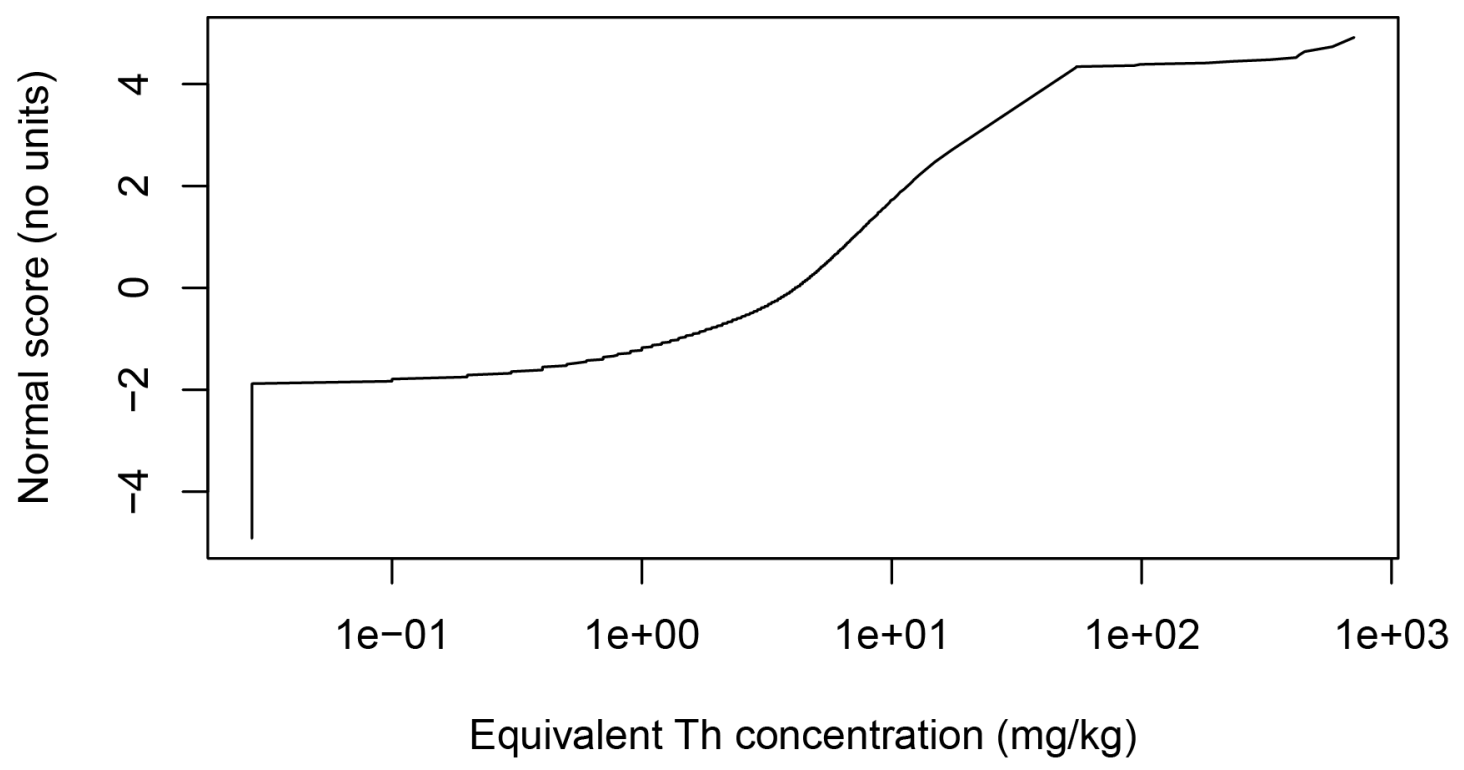

Figure 18. Normal score transformation for the equivalent thorium (eTh) concentrations. ( $\mathrm{mg} / \mathrm{kg}$; milligrams per kilogram)

All four scatterplots (fig. 19) show that the ilr-transformed concentrations are widely scattered about the best-fitting straight lines. The proportion of the variance explained by the linear regression $R^{2}$ is $0.219,0.173$, and 0.0972 for $\mathrm{La}, \mathrm{Y}$, and $\mathrm{Ti}$, respectively. That is, normal score (from eTh concentration) explains only a small portion of the variation in the data. One reason is that the normal scores and ilr-transformed concentrations measure different things- the normal scores (of eTh concentration) pertain to gamma rays radiated from surface materials within a fixed region, whereas La, $\mathrm{Y}$, and Ti ilr-transformed concentrations pertain to individual stream sediments samples. Another reason is that the survey lines and sample locations differ-normal scores (from the eTh concentrations) had to be interpolated to the sample locations.

Because the proportions $R^{2}$ are small, it is tempting to dismiss the regressions and hence to dismiss normal score as an explanatory variable. We believe that such action would be a mistake. The 
regression lines are consistent with the data and with our independent understanding of the geology. Therefore, it makes sense that they should be used as an explanatory variable.

A.

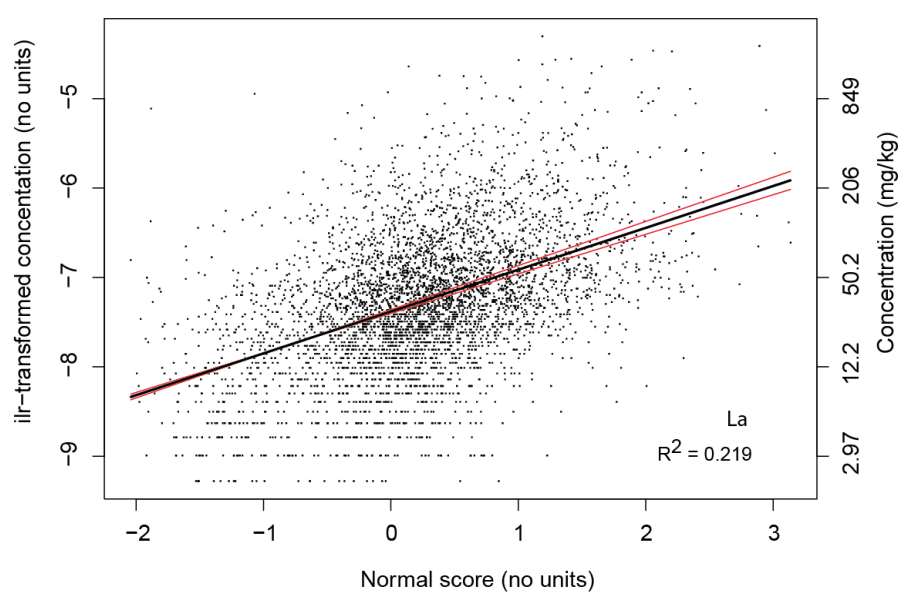

C.

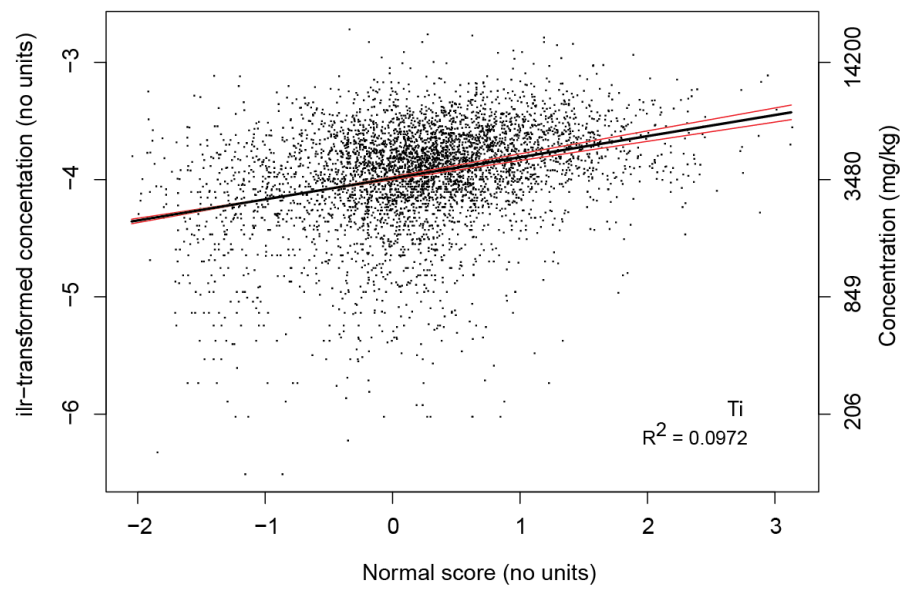

B.

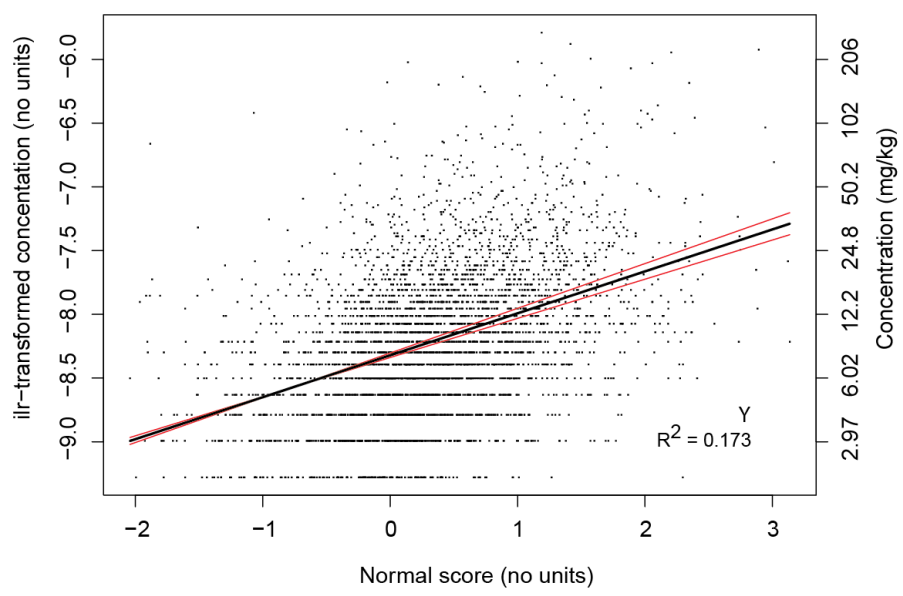

D.

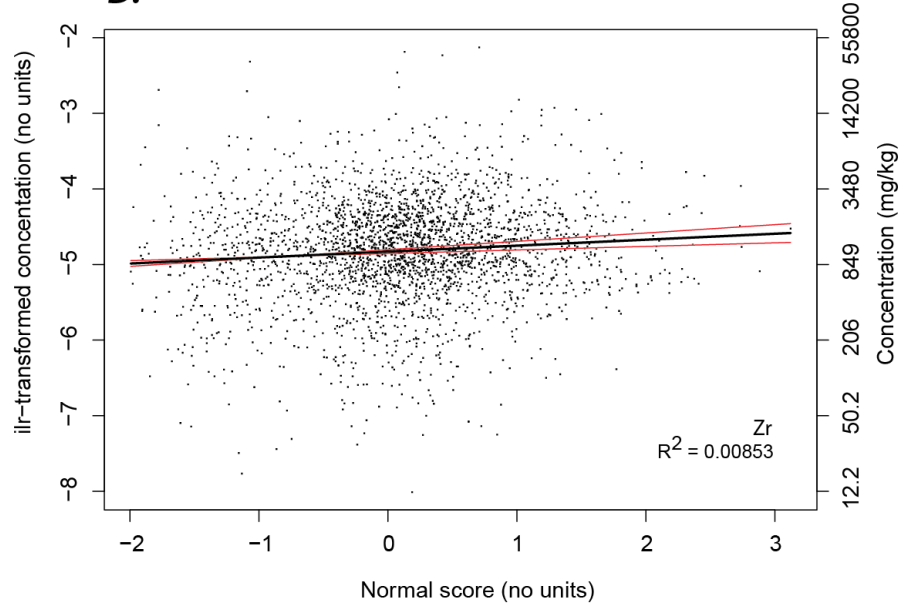

Figure 19. Scatterplots showing the relations between the normal score (from the equivalent thorium [eTh] concentration) and the ilr-transform of $A, \mathrm{La} ; B, \mathrm{Y} ; \mathrm{C}$, Ti; and $D, \mathrm{Zr}$ concentrations. The black solid lines represent the best-fitting straight line to the data; the associated red dashed lines represent the 95-percent confidence interval due to uncertainty in the slope and intercept parameters. The horizontal banding is due to rounding of the reported concentration to one significant digit. The lowest horizontal bands correspond to lower reporting limits. (ilr, isometric log-ratio; mg/kg; milligrams per kilogram)

For $\mathrm{Zr}$, the proportion of the variance explained by the linear regression $R^{2}$ is 0.00853 (fig. $19 D$ ). That is, normal score (for eTh concentration) explains practically none of the variation in the data. This result is expected because the spatial distributions of $\mathrm{Zr}$ and eTh differ significantly (fig. $10 D$ and fig. 17). 


\section{Summary}

\subsection{Findings}

This report summarizes the first steps of a regional investigation of the Coastal Plain sediments in the southeastern United States. The first steps include assembling the pertinent data, determining its limitations, analyzing its properties, and analyzing the relations among the different data types. The analysis focuses on $\mathrm{Ti}, \mathrm{La}, \mathrm{Y}$, and $\mathrm{Zr}$ concentrations that were measured from samples of stream sediments; these four elements are chosen because Ti is a proxy for ilmenite, rutile and leucoxene; $\mathrm{La}$ for monazite; Y for xenotime; and $\mathrm{Zr}$ for zircon.

Quantile maps for La, Y, and Ti are generally similar. Concentrations tend to be high near the Fall Line and decrease as the distance from the Fall Line increases. Concentrations also tend to be high near the coastlines of Georgia and southeastern South Carolina. The likely cause of the similarity is that the associated minerals were affected by similar geologic processes. In contrast, the quantile map for $\mathrm{Zr}$ is characterized by small-scale anomalies; it lacks regional-scale features observed in the other three quantile maps. We speculate that the geologic processes governing the distribution of zircon differed from those governing the distributions of the other heavy minerals.

The concentrations of $\mathrm{La}, \mathrm{Y}$, and Ti tend to be relatively high in those watersheds that adjoin the Fall Line. Also, the distributions of those concentrations change systematically along the Fall Line. It is tempting to assume that this systematic change is related to the watershed, but this apparent relationship might reflect just an independent regional trend that spans many watersheds. The concentrations of La, Y, and Ti tend to be high near the Fall Line and decrease as the distance from the Fall Line increases. Three linear regressions quantifying this relation for the three elements account for 10, 15, and 18 percent of the variation in the data, so we infer that that the concentrations are affected by additional geologic processes. The concentrations of $\mathrm{La}, \mathrm{Y}$, and Ti tend to increase as the normal score for the eTh concentration increases. Three linear regressions quantifying this relation for the three elements account for 10,17 and 22 percent of the variation in the data; these modest percentages are reasonable considering the differences in the measurements. In contrast to these relations, the concentration of $\mathrm{Zr}$ is unrelated to the watershed, the distance from the Fall Line, and normal score for the eTh concentration.

\subsection{Suggested Changes}

Based upon this initial analysis of the data, we suggest the following changes to the continuing investigation because they will improve the integrated spatial modeling when it is performed.

- Consider alternative ways of modeling the spatial distribution of Zr. The spatial distribution of the $\mathrm{Zr}$ concentrations lacks regional-scale features (fig. 10D) that are the focus of integrated spatial modeling. In addition, the $\mathrm{Zr}$ concentrations are poorly predicted by the potential explanatory variables (section 4.2) that are needed for integrated spatial modeling.

- Modify the study area. The small areas from the Piedmont that were included in the study area (section 2.4) are not favorable areas for mineral development and complicate the analysis. These areas should be deleted from the study area.

- Focus on multiple geologic processes. When we began the initial analysis, we believed that the primary geologic processes involved fluvial transport of minerals from the Piedmont and subsequent marine transport and deposition. Consequently, we assumed that the associated element concentrations should decrease as the distance from the Fall Line increases. Indeed, the regression based on this assumption explains some of the variation in the data (section 4.2.3). However, we now suspect that additional geologic processes significantly affect the spatial 
distribution of the heavy minerals; these additional processes include fluvial process along the modern rivers and marine processes along both the modern and ancient Atlantic coast. These and other additional geologic processes should be incorporated into the spatial modeling.

- Include soil geochemical data. There are approximately 400 sites within the study area at which soil samples were recently collected (Smith and others, 2014). Concentrations of $\mathrm{La}, \mathrm{Ce}, \mathrm{Y}, \mathrm{Ti}$, and approximately 40 other elements were measured. This information may be especially helpful in the spatial modeling because the sample medium was the soil, the very medium in which mining will occur.

\section{Acknowledgments}

This work was funded by the Minerals Program of the U.S. Geological Survey under two projects: "Geophysical and geochemical approaches to evaluating REE potential in the southeastern U.S." and "Geophysical methods development."

\section{References Cited}

Aitchison, J., 1986, Statistical analysis of compositional data: Chapman and Hall, Inc., re-issued in 2003 by The Blackburn Press, $416 \mathrm{p}$.

Bates, R.G., 1962, Airborne radioactivity surveys-A geologic exploration tool: Southeastern Geology, v. 3, no. 4, p. 221-230.

Berquist, C.R., 1987, Minerals in high-level gravel deposits along the Fall Zone of Virginia: Virginia Minerals, v. 33, no. 4, p. 37-40.

Briggs, P.H., 2002, The determination of forty elements in geological and botanical samples by inductively coupled plasma-atomic emission spectrometry, chap. G of Taggart, J.E., ed., Analytical methods for chemical analysis of geologic and other materials: U.S. Geological Survey Open-File Report 02-223, p. 1-18, accessed July 2014 at http://pubs.er.usgs.gov/publication/ofr02223.

Buccianti, Antonella, and Pawlowsky-Glahn, Vera, 2005, New perspectives on water chemistry and compositional data analysis: Mathematical Geology, v. 37, no. 6, p. 703-727.

Budahn, J.R. and Wandless, G.A., 2002, Instrumental neutron activation by abbreviated count: U.S. Geological Survey Open-File Report 02-223, p. Y1-Y9, accessed October 2014 at http://pubs.usgs.gov/of/2002/ofr-02-0223/Y15INAA-SHORT_M.pdf.

Carpenter, R.H., and Carpenter, S.F., 1991, Heavy mineral deposits in the Upper Coastal Plain of North Carolina and Virginia: Economic Geology, v. 86, no. 8, p. 1657-1671.

Chayes, F., 1960, On correlation between variables of constant sum: Journal of Geophysical Research, v. 65 , no. 12 , p. $4185-4193$.

Duval, J.S., 1990, Modern aerial gamma-ray spectrometry and regional potassium map of the conterminous United States: Journal of Geochemical Exploration, v. 39, nos. 1-2, p. 249-253.

Duval, J.S., 1999, Aerial gamma-ray surveys of the conterminous United States and Alaska: U.S. Geological Survey Open-File Report 99-562-A through 99-562-M. [14 reports published on 14 CD-ROMs.]

Egozcue, J.J., Pawlowsky-Glahn, Vera, Mateu-Figueras, Glòria, and Barceló-Vidal, Carles, 2003, Isometric logratio transformations for compositional data analysis: Mathematical Geology, v. 35, no. 3, p. 279-300.

Ferguson, R.B., Price, Van, and Baucom, E.I., 1976, Field manual for stream sediment reconnaissance: Grand Junction, Colo., U.S. Department of Energy, E I Du Pont De Nemours \& Company, Savannah 
River Laboratory, Report DPST-76-358, GJBX-30(77), accessed July 2014 at http://pubs.usgs.gov/of/1997/ofr-97-0492/nurepubs.htm.

Force, E.R., 1976, Metamorphic source rocks of titanium placer deposits—A geochemical cycle: U.S. Geological Survey Professional Paper 959-B, 16 p.

Force, E.R., 1991, Geology of titanium-mineral deposits: Geological Society of America Special Paper 259, $112 \mathrm{p}$.

Friedman, G.M., and Sanders, J.E., 1978, Principles of sedimentology: New York, John Wiley \& Sons, Inc., 792 p.

Frihy, O.E., 1994, Discrimination of accreted and eroded coasts using heavy mineral compositions of the Nile Delta beach sands, Egypt: Sedimentology, v. 41, p. 905-912.

Gaines, R.V., Skinner, H.C.W., Foord, E.E., Mason, B., and Rosenzweig, Abraham, 1997, Dana's new mineralogy (8th ed.): New York, John Wiley \& Sons, Inc., 1,819 p.

Galloway, W.E., Whiteaker, T.L., and Ganey-Curry, Patricia, 2011, History of Cenozoic North American drainage basin evolution, sediment yield, and accumulation in the Gulf of Mexico basin: Geosphere, v. 7, no. 4, p. 938-973, doi:10.1130/GES00647.1.

Garnett, R.H.T., and Bassett, N.C., 2005, Placer deposits, in Hedenquist, J.W., Thompson, J.F.H., Goldfarb, R.J., and Richards, J.P., eds., Economic geology-One hundredth anniversary volume (1905-2005): Littleton, Colorado, Society of Economic Geologists, p. 813-843.

Gregory, A.F., 1960, Geological interpretation of aeroradiometric data: Geological Survey of Canada Bulletin 66, $29 \mathrm{p}$.

Goonan, T.G., 2011, Rare earth elements-End use and recyclability: U.S. Geological Survey Scientific Investigations Report 2011-5094, 15 p., http://pubs.usgs.gov/sir/2011/5094/.

Grosz, A.E., San Juan, F.C., Jr., and Reid, J.C., 1992, Heavy-mineral concentrations associated with some gamma-ray aeroradiometric anomalies over Cretaceous sediments in North CarolinaImplications for locating placer mineral deposits near the Fall Zone: U.S. Geological Survey OpenFile Report 92-396, 27 p.

Hill, P.L., Kucks, R.P., and Ravat, Dhananjay, 2009, Aeromagnetic and aeroradiometric data for the conterminous United States and Alaska from the National Uranium Resources Evaluation (NURE) Program of the U.S. Department of Energy: U.S. Geological Survey Open-File Report 2009-1129, http://pubs.usgs.gov/of/2009/1129/.

Hoffman, E.L., 1992, Instrumental neutron activation in geoanalysis: Journal of Geochemical Exploration, vol. 44, p. 297-319.

Hou, Baohong, Alley, N.F., Frakes, L.A., Stoian, L., and Crowley, W.M., 2006, Eocene stratigraphic succession in the Eucla basin of South Australia and correlation to major regional sea-level events: Sedimentary Geology, v. 183, nos. 3-4, p. 297-319.

Hou, Baohong, Frakes, L.A., Sandiford, M., Worrall, L., Keeling, J., Alley, N.F., 2008, Cenozoic Eucla basin and associated paleovalleys, southern Australia - Climatic and tectonic influences on landscape evolution, sedimentation and heavy mineral accumulation: Sedimentary Geology, v. 203, nos. 1-2, p. 112-130.

Hou, Baohong, Keeling, John, Reid, Anthony, Fairclough, Martin, Warland, Ian, Belousova, Elena, Frakes, Larry, and Hocking, Roger, 2011, Heavy mineral sands in the Eucla Basin, southern Australia-Deposition and province-scale prospectivity: Economic Geology, v. 106, no. 4, p. $687-712$.

Hurlbut, C.S., Jr., and Klein, Cornelis, 1977, Manual of mineralogy: New York, John Wiley \& Sons, Inc., $532 \mathrm{p}$. 
Iluka Resources, 2014, Operations: Iluka Resources, accessed December 2014, at http://www.iluka.com/company-overview/operations.

Luepke, Gretchen, ed., 1984, Stability of heavy minerals in sediments: New York, Van Nostrand Reinhold Company, 306 p.

MacNeil, F.S., 1950, Pleistocene shore lines in Florida and Georgia: U.S. Geological Survey Professional Paper 221-F, p. 95-107, 7 plates.

McKellar, J.B., 1975, The eastern Australian rutile province, in Knight, C.I., ed., Economic geology of Australia and Papau New Guinea: Australian Institute of Mining and Metallurgy, Volume 1-Metals, p. 1055-1062.

Mertie, J.B., Jr., 1953, Monazite deposits in the southeastern Atlantic states: U.S. Geological Survey Circular 237, 31 p., http://pubs.er.usgs.gov/publication/cir237.

Mertie, J.B. Jr., 1975, Monazite placers in the southeastern Atlantic states: U.S. Geological Survey Bulletin 1390, 41 p., http://pubs.er.usgs.gov/publication/b1390.

Mills, S.J., Hatert, Frédéric, Nickel, E.H., and Ferraris, Giovanni, 2009, The standardisation of mineral group hierarchies-Application to recent nomenclature proposals: European Journal of Mineralogy, v. 21, p. 1073-1080.

Moxham, R.H., 1960, Airborne radioactivity surveys in geologic exploration: Geophysics, v. 25, no. 2 , p. 408-432.

Neiheisel, James, 1962, Heavy-mineral investigations of Recent and Pleistocene sands of the lower coastal plain of Georgia: Geological Society of America Bulletin, v. 73, no. 3, p. 365-374.

Ni, Yunxiang, Hughes, J.M., and Mariano, A.N., 1995, Crystal chemistry of the monazite and xenotime structures: American Mineralogist, v. 80, p. 21-26.

Overstreet, W.C., 1967, The geologic occurrence of monazite: U.S. Geological Survey Professional Paper 530, 327 p., http://pubs.er.usgs.gov/publication/pp530.

Overstreet, W.C., White, A.M., Whitlow, J.W., Theobald, P.K., Jr., Caldwell, D.W., and Cuppels, N.P., 1968, Fluvial monazite deposits in the southeastern United States: U.S. Geological Survey Professional Paper 568, 85 p., 9 plates.

Pawlowsky-Glahn, Vera, and Buccianti, Antonella, eds., 2011, Compositional data analysis-Theory and applications: Chichester, United Kingdom, John Wiley \& Sons, Ltd., 378 p.

Pirkle, F.L., Pirkle, W.A., and Pirkle, E.C., 2007, Heavy-mineral sands of the Atlantic and Gulf Coastal Plains, USA, chap. 45 of Maria, A.M., and David, T.W., eds.: Elsevier, Developments in Sedimentology, v. 58, p. 1144-1232.

Pitkin, J.A., 1968, Airborne measurements of terrestrial radioactivity as an aid to geologic mapping: U.S. Geological Survey Professional Paper 516-F, 29 p., http://pubs.er.usgs.gov/publication/pp516F.

Rapp, R.P., and Watson, E.B., 1986, Monazite solubility and dissolution kinetics-Implications for the thorium and light rare earth chemistry of felsic magmas: Contributions to Mineralogy and Petrology, v. 94, p. 304-316.

Reimann, Clemans, Filzmoser, Peter, Garrett, R.G., and Dutter, Rudolf, 2008, Statistical data analysis explained-Applied environmental statistics with R: Chichester, United Kingdom, John Wiley \& Sons, Ltd., 343 p.

Roy, P.S., 1999, Heavy mineral beach placers in southeastern Australia-Their nature and genesis: Economic Geology, v. 94, no. 4, p. 567-588.

Schabenberger, Oliver, and Gotway, C.A., 2005, Statistical methods for spatial data analysis: Boca Raton, Fla., Chapman and Hall/CRC, 488 p.

Smith, D.B., Smith, S.M., and Horton, J.D., 2013, History and evaluation of national-scale geochemical data sets for the United States: Geoscience Frontiers, v. 4, p. 167-183. 
Smith, D.B., Cannon, W.F., Woodruff, L.G., Solano, Federico, and Ellefsen, K.J., 2014, Geochemical and mineralogical maps for soils of the conterminous United States: U.S. Geological Survey OpenFile Report 2014-1082, 386 p., http://dx.doi.org/10.3133/ofr20141082.

Smith, S.M., 1997, National Geochemical Database - Reformatted data from the National Uranium Resource Evaluation (NURE) Hydrogeochemical and Stream Sediment Reconnaissance (HSSR) program: U.S. Geological Survey Open-File Report 97-492, http://pubs.er.usgs.gov/publication/ofr97492.

Soller, D.R., 1988, Geology and tectonic history of the Lower Cape Fear River valley, southeastern North Carolina: U.S. Geological Survey Professional Paper 1466-A, 60 p., 1 plate.

Staatz, M.H., Hall, R.B., Macke, D.L., Armbrustmacher, T.J., and Brownfield, I.K., 1980, Thorium resources of selected regions in the United States: U.S. Geological Survey Circular 824, 32 p.

Tukey, J.W., 1977, Exploratory data analysis: London, Addison-Wesley Publishing Company, 688 p. U.S. Geological Survey, 2004, The National Geochemical Survey: U.S. Geological Survey Open-File Report 2004-1001, http://pubs.er.usgs.gov/publication/ofr20041001.

van den Boogaart, K.G., and Tolosana-Delgado, R., 2013, Analyzing compositional data with R: Berlin, Springer-Verlag, $258 \mathrm{p}$.

Van Gosen, B.S., Fey, D.L., Shah, A.K., Verplanck, P.L., and Hoefen, T.M., 2014, Deposit model for heavy-mineral sands in coastal environments: U.S. Geological Survey Scientific Investigations Report 2010-5070-L, 51 p., http://dx.doi.org/10.3133/sir20105070L.

Young, C.A., and Luttrell, G.H., eds., 2012, Separation technologies for minerals, coal and earth resources: Littleton, Colo., Society for Mining, Metallurgy, and Exploration, 756 p. 